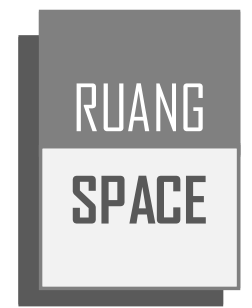

\title{
PENGENDALIAN ALIH FUNGSI LAHAN PERTANIAN DI KAWASAN PERKOTAAN MANGUPURA KABUPATEN BADUNG
}

\author{
Oleh: I Putu Anom Widiarsa', Gusti Ayu Made Suartika²
}

\begin{abstract}
This article aims at analyzing determining aspects that must be incorporated in to the process of developing a strategy to control land development. It converses this objective by taking the increasing rate of agricultural land conversion in Mangupura urban area, of Badung Regency-Bali, as its case study. The study was carried out using a qualitative approach. The findings demonstrate the driving factors behind such a conversion are classified into four categories, including social, economical, environmental and regulatory forces. Learning from the dynamic of land development of Mangupura area, the study subsequently comes out with a conclusion that for efficiency and success, the strategy to control land use changes has to embrace two basic aspects of: (i) identification and clarification of instruments to regulate spatial changes, and (ii) the allocation of agency/s assigned to carry out the controlling roles. It is further emphasized that attempts to rule spatial development should take both of the aforementioned determining forces and basic aspects influencing the success of the control strategy, into account.
\end{abstract}

Keywords: conversion, agricultural land, land use control and strategy

\begin{abstract}
Abstrak
Artikel ini bertujuan merumuskan aspek-aspek yang wajib diperhatikan dalam pembangunan strategi pengendalian pemanfaatan lahan, dengan studi kasus alih fungsi lahan pertanian yang semakin meningkat di Kawasan Perkotaan Mangupura, Kabupaten Badung. Penelitian yang melandasi penyusunannya dilaksanakan dengan menggunakan pendekatan kualitatif. Hasil studi menunjukan bahwa faktor pendorong terjadinya alih fungsi lahan pertanian bisa diklasifikasikan ke dalam empat kategori, termasuk aspek sosial, ekonomi, lingkungan dan regulasi. Sedangkan strategi pengendalian yang dapat dilaksanakan dengan mempertimbangkan dua aspek dasar, yaitu pembangunan instrumen pengendalian pemanfaatan ruang, dan instansi pelaksana kegiatan pengendalian pemanfaatan ruang. Secara keseluruhan, artikel ini bernaung pada ide bahwa efisiensi serta kesuksesan upaya kontrol pembangunan spasial, yang terjadi di Kabupaten Badung khususnya, wajib mempertimbangkan faktor pengaruh dan komponen penentu yang mengarahkan kepada strategi pengendalian pemanfaatan ruang.
\end{abstract}

Kata kunci: alih fungsi, lahan pertanian, strategi pengendalian

1 Program Studi Magister Arsitektur Universitas Udayana.

Email: anomwidiarsa@yahoo.com

2 Program Studi Magister Arsitektur Universitas Udayana.

Email: ayusuartika@unud.ac.id 


\section{Pendahuluan}

Perkembangan yang terjadi di suatu kawasan perkotaan akan berpengaruh terhadap tata guna lahan. Perkembangan kawasan perkotaan baik secara langsung maupun tidak langsung, akan membutuhkan lahan yang lebih luas untuk mewadahi kehidupan masyarakat. Tata guna lahan di kawasan perkotaan dimanfaatkan untuk memfasilitasi berbagai kegiatan, seperti permukiman, pariwisata, industri, perdagangan dan jasa, serta mewadahi berbagai sarana prasarana penunjang lainnya. Namun di sisi lain ketersediaan lahan yang tetap dan tidak berubah, menyebabkan terjadinya permasalahan dalam pemanfaatan lahan di kawasan perkotaan (Puspasari, 2012: 2). Keterbatasan dari ketersediaan lahan akan mengakibatkan terjadinya pemanfaatan lahan di luar rencana tata ruang yang telah ditetapkan, salah satunya adalah terjadinya alih fungsi terhadap lahan pertanian. Secara umum, alih fungsi lahan pertanian merupakan dampak dari proses transformasi struktur ekonomi dan demografis, yang menuntut adanya transformasi alokasi sumberdaya lahan dari pertanian ke non pertanian (Kustiawan, 1997: 49). Alih fungsi lahan pertanian dapat dikatakan sebagai konsekuensi dari perkembangan suatu wilayah. Semakin tingginya perkembangan di kawasan perkotaan, dan laju pertumbuhan penduduk, maka semakin besar pula potensi terjadinya alih fungsi lahan pertanian pada kawasan perkotaan tersebut (Catur, 2010: 39).

Kawasan Perkotaan Mangupura yang telah ditetapkan sebagai Ibukota Kabupaten Badung sejak tanggal 16 Nopember 2009, berdasarkan Peraturan Pemerintah Nomor 67 Tahun 2009 tentang Pemindahan Ibukota Kabupaten Badung, juga telah mengalami perkembangan yang cukup signifikan. Hal ini tidak lepas dari pengaruh perkembangan kawasan perkotaan, kegiatan sektor pariwisata, dan laju pertumbuhan penduduk yang semakin meningkat dari waktu ke waktu. Keterbatasan ketersediaan lahan, dibandingkan dengan semakin tingginya kebutuhan akan sumber daya ini, secara tidak langsung akan mengakibatkan terjadinya alih fungsi lahan. Sumber daya keruangan yang sering menjadi sasaran dalam proses ini adalah lahan pertanian. Ini secara nyata bisa diobservasi kejadiannya di Kawasan Perkotaan Mangupura, bahkan berkurangnya lahan pertanian akibat terjadinya alih fungsi lahan saat ini sudah mencapai taraf yang mengkhawatirkan.

Kebijakan dan peraturan yang berkaitan dengan pengendalian alih fungsi lahan pertanian, telah banyak ditetapkan oleh pemerintah, baik pusat maupun daerah. Kebijakan ini memiliki wujud yang beragam, baik yang berupa undang-undang, peraturan pemerintah, peraturan daerah, maupun surat keputusan pemerintah daerah. Akan tetapi, yang sering menjadi pertanyaan adalah keberhasilan implementasinya di lapangan yang secara nyata dapat dikatakan belum terlaksana secara optimal. Salah satu penyebab yang bisa disampaikan disini, yang diperoleh berdasarkan hasil pengamatan di lapangan adalah masih kurangnya dukungan data, dan minimnya sikap proaktif dari pemerintah daerah, maupun masyarakat dalam pengendalian alih fungsi lahan pertanian. Pernyataan ini juga didukung oleh Harsono (2008) dalam bukunya yang berjudul Hukum Agraria Indonesia, Sejarah Pembentukan Undang Undang Pokok Agraria, Isi dan Pelaksanaannya.

Data awal menunjukan bahwa, sebagian besar lahan pertanian di Kawasan Perkotaan Mangupura telah dialihfungsikan menjadi kawasan permukiman, perdagangan dan jasa, serta industri. Alih fungsi ini terjadi pada level tertinggi di Kelurahan Sempidi, dan 
Kelurahan Sading (Dinas Cipta Karya Kabupaten Badung, 2015). Pemerintah Daerah Kabupaten Badung menaruh perhatian besar terhadap kondisi masifnya alih fungsi lahan pertanian di Kawasan Perkotaan Mangupura. Kondisi ini mengindikasikan telah terjadinya ketidakefektifan, dan inefisiensi pelaksanaan program pemerintah khususnya dalam penataan ruang. Telah menjadi pengetahuan umum, apabila keadaan ini tidak diantisipasi dan diminimalisir, alih fungsi lahan pertanian akan mempengaruhi keberlanjutan ketersediaan sumber pangan, kualitas lingkungan alamiah, kehidupan sosial, dan keberlangsungan ekonomi masyarakat di Kawasan Perkotaan Mangupura khususnya, dan wilayah Kabupaten Badung pada umumnya.

Berdasarkan sirkumstansi-sirkumstansi yang dipaparkan di atas, maka studi yang didokumentasikan di dalam artikel ini mencoba mengkaji dan menganalisa lebih jauh tentang tiga hal utama, yaitu (i) perkembangan alih fungsi lahan pertanian; (ii) kondisikondisi yang telah memicu terjadinya alih fungsi lahan pertanian; dan (iii) strategi pengendalian alih fungsi lahan pertanian di Kawasan Perkotaan Mangupura Kabupaten Badung.

\section{Metode Penelitian}

Studi yang dilaksanakan menerapkan pendekatan deskriptif kualitatif, yang bertujuan untuk menggambarkan secara sistimatik mengenai situasi dan kondisi obyek penelitian secara akurat. Lofland, 1984 dalam (Maleong, 2007: 157) menjabarkan bahwa sumber data utama dalam penelitian kualitatif berupa kata-kata, dan gambaran tindakan atau aktivitas, yang didukung oleh beragam data sekunder yang relevan. Data primer dari penelitian ini telah diperoleh melalui pelaksanaan observasi fisik, dan wawancara tidak terstruktur. Sedangkan data sekunder, diusahakan melalui kajian berbagai literatur terkait beserta data-data hasil studi yang dilaksanakan tim peneliti sebelumnya, maupun oleh badan-badan pemerintah, maupun lembaga-lembaga yang ditugaskan oleh pemerintah.

Pendekatan yang diterapkan dalam pemilihan responden adalah teknik purposive sampling. Keputusan ini diambil dengan memperhatikan adanya keterbatasan waktu, tenaga, dan biaya dari pihak peneliti, sehingga tidak dapat mengambil sampel yang besar. Adapun kriteria utama yang dipakai dalam memilih responden dalam penelitian ini, seperti halnya yang ditekankan oleh Sugiyono (2014: 300) ketika purposive sampling diterapkan dalam sebuah penelitian, adalah calon responden memiliki ketertarikan dan memahami secara mendalam fenomena alih fungsi lahan pertanian yang khususnya terjadi di Kawasan Perkotaan Mangupura Kabupaten Badung, atau menjadi bagian dari proses tersebut. Pertimbangan ini diambil dengan harapan, bahwa data yang diperoleh akan mampu secara relevan mendukung proses pencarian jawaban terhadap ketiga tujuan penelitian. Setelah melalui kajian awal maka diputuskan bahwa responden yang dipilih untuk studi ini mewakili enam (6) kelompok yang terlibat dalam proses alih fungsi lahan pertanian di Kawasan Perkotaan Mangupura, yaitu: (i) wakil masyarakat, baik penduduk asli maupun pendatang; (ii) tokoh masyarakat; (iii) aparatur pemerintahan desa/kelurahan dan kecamatan; (iv) aparatur Pemerintah Daerah Kabupaten Badung yang memiliki tugas terkait dengan penataan ruang; (v) pihak pengembang atau developer; (vi) serta pihak pengamat tata ruang. 


\section{Kawasan Perkotaan Mangupura sebagai Pusat Pertumbuhan Kota Baru}

Menurut Peraturan Pemerintah Nomor 67 Tahun 2009 tentang Pemindahan Ibukota Kabupaten Badung, dari wilayah Kota Denpasar ke wilayah Kecamatan Mengwi, Kabupaten Badung, Provinsi Bali, menjabarkan istilah Mangupura mengandung arti ibukota yang menawan hati, ibukota yang merupakan tempat untuk mencari keindahan, kedamaian dan kebahagiaan, ibukota yang mendatangkan kesejahteraan bagi masyarakatnya, dan ibukota yang menumbuhkan rasa aman bagi masyarakatnya. Kawasan Perkotaan Mangupura yang terletak di Kecamatan Mengwi, yaitu pada koordinat 08³6'10" LS dan 115¹0'43" BT, dan luasnya yaitu 3.587 hektar. Secara administrasi batas-batas wilayah Kawasan Perkotaan Mangupura antara lain: a) sebelah utara berbatasan dengan Desa Werdhi Bhuana, dan Desa Baha; b) sebelah timur berbatasan dengan Desa Penarungan, dan Desa Darmasaba; c) sebelah selatan berbatasan dengan Desa Buduk, Desa Dalung, dan Kota Denpasar; dan d) sebelah barat berbatasan dengan Kabupaten Tabanan. Lokasi dan batas wilayah Kawasan Perkotaan Mangupura dapat dilihat pada Gambar 1.

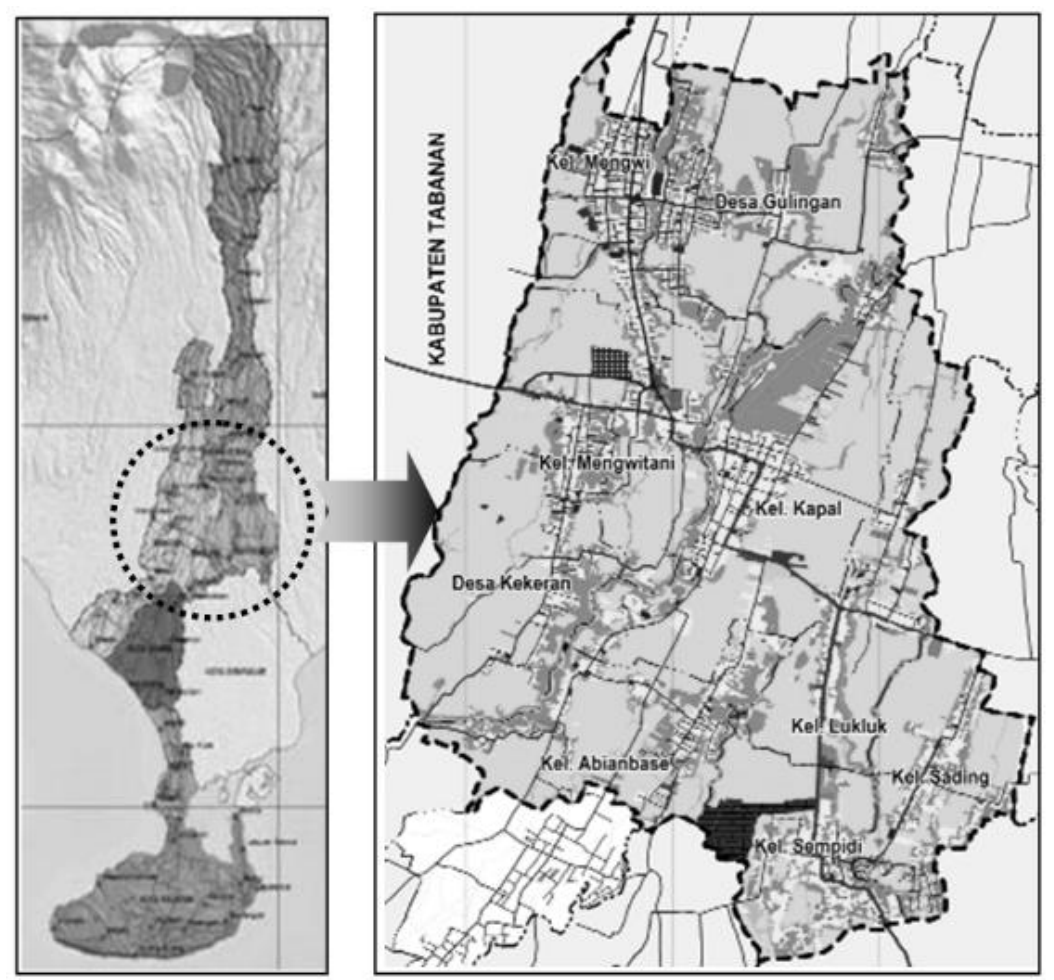

Gambar 1. Peta Lokasi Kawasan Perkotaan Mangupura

Sumber: Bapedda Litbang Kabupaten Badung, 2011: 53

Lingkup wilayah Kawasan Perkotaan Mangupura meliputi sembilan desa/kelurahan, yang terdiri dari lima desa yaitu Desa Mengwi, Desa Gulingan, Desa Mengwitani, Desa Kekeran, dan empat kelurahan yaitu Kelurahan Kapal, Kelurahan Lukluk, Kelurahan Sading, Kelurahan Sempidi, dan Kelurahan Abianbase. Luas masing-masing desa dan kelurahan dapat dilihat pada Tabel 1 . 
Tabel 1. Luas Perkotaan Mangupura berdasarkan Desa/Kelurahan

\begin{tabular}{clccccc}
\hline No & Desa/Kelurahan & $\begin{array}{c}\text { Luas } \\
\left(\mathrm{km}^{2}\right)\end{array}$ & $\begin{array}{c}\text { Luas } \\
(\%)\end{array}$ & $\begin{array}{c}\text { Jumlah } \\
\text { Banjar }\end{array}$ & $\begin{array}{c}\text { Jumlah } \\
\text { Lingk. }\end{array}$ & $\begin{array}{c}\text { Desa } \\
\text { Adat }\end{array}$ \\
\hline 1 & Kelurahan Abianbase & 401 & 11,18 & & 13 & 3 \\
2 & Kelurahan Sempidi & 346 & 9,65 & & 9 & 2 \\
3 & Kelurahan Sading & 284 & 7,92 & & 9 & 1 \\
4 & Kelurahan Lukluk & 314 & 8,75 & & 9 & 3 \\
5 & Kelurahan Kapal & 562 & 15,67 & & 16 & 1 \\
6 & Desa Kekeran & 405 & 11,29 & 7 & & 1 \\
7 & Desa Mengwitani & 420 & 11,71 & 11 & & 2 \\
8 & Desa Mengwi & 378 & 10,54 & 11 & & 1 \\
9 & Desa Gulingan & 477 & 13,30 & 13 & & 1 \\
\hline \multicolumn{7}{c}{ Kawasan Perkotaan } \\
$\quad$ Mangupura & $\mathbf{3 . 5 8 7}$ & $\mathbf{1 0 0 , 0 0}$ & $\mathbf{4 2}$ & $\mathbf{5 6}$ & $\mathbf{1 5}$ \\
\hline
\end{tabular}

Sumber: Badan Pusat Statistik Kabupaten Badung, Kecamatan Mengwi Dalam Angka, 2016

Berbicara perubahan pemanfaatan lahan, perluasan dan atau pembangunan kawasan perkotaan baru, dalam hal ini Kawasan Perkotaan Mangupura, akan berimplikasi terhadap perubahan nilai ekonomis lahan. Nilai ini akan sangat dipengaruhi oleh posisinya terhadap jaringan transportasi dan pusat aktivitas kota (Daldjoeni, 1992: 35). Pernyataan ini berkaitan dengan teori yang dikemukakan oleh Johan Heinrich Von Thunen dalam (Hermit, 2009:98), seorang ekonom dari Jerman yang mengkaji tata guna lahan perkotaan, dilihat dari aspek nilai ekonomis lahan. Dia menjelaskan bahwa harga tanah ditentukan oleh panjang jarak lokasi geografis lahan terhadap pusat kegiatan kota atau Central Business District (CBD). Semakin dekat lokasi lahan terhadap CBD, maka semakin tinggi pula harga dan permintaan terhadap lahan tersebut. Sebaliknya, semakin jauh lokasi tanah terhadap CBD, maka semakin rendah pula harga dan permintaan terhadap tanah tersebut. Perubahan tata guna lahan di kawasan perkotaan menurut Von Thunen dapat dilihat pada Gambar 2.

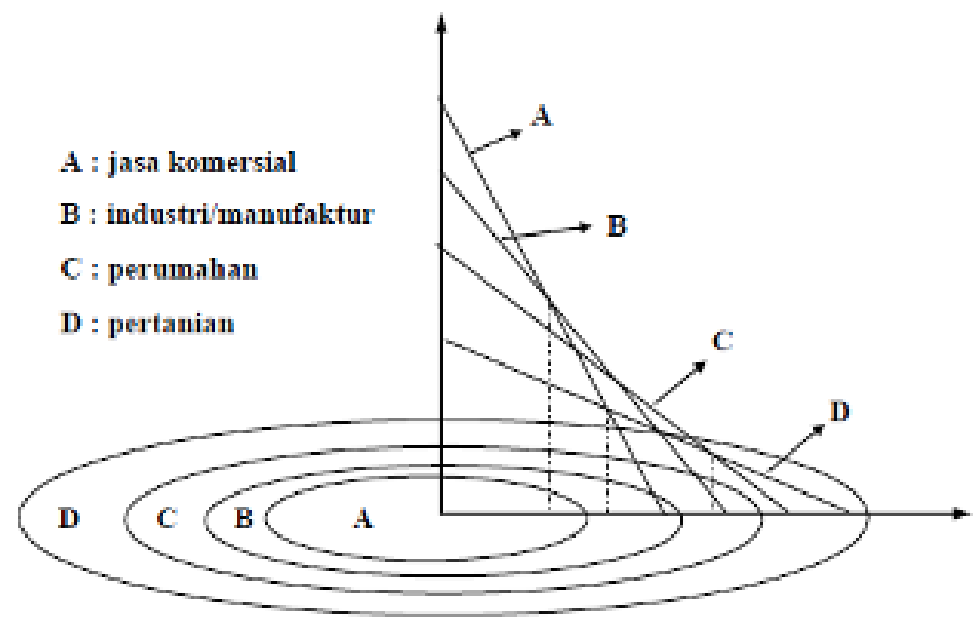

Gambar 2. Penentuan Locational Rent Function Menurut Von Thunen Sumber: Bappenas, 2006: 85 
Adanya pemusatan kegiatan di kawasan perkotaan, telah meningkatkan daya tarik lahan di kawasan ini, yang pada akhirnya akan mengelevasi nilai ekonomisnya. Hal ini terbukti ketika kawasan perkotaan dipenuhi oleh beragam bangunan komersial, seperti pertokoan dan industri. Ini belum memperhitungkan pembangunan fungsi-fungsi perkantoran, dan permukiman penduduk. Berdasarkan Gambar 2 di atas, dapat dilihat pada zona lingkaran A menunjukkan pemanfaatan lahan untuk fungsi komersial (pusat kota). Di wilayah ini nilai ekonomis lahan mencapai nilai tertinggi. Zona B, C, dan D merepresentasikan penggunaan lahan untuk industri, perumahan, dan pertanian. Meningkatnya nilai ekonomis lahan di kawasan A akan meningkatkan nilai tukar jasa-jasa komersial, sehingga menggeser kurva nilai ekonomis lahan A ke kanan, dan sebagian dari area lingkaran B (kawasan industri) terkonversi menjadi A. Demikian seterusnya, sampai kita melihat bagaimana lahan pertanian (lingkaran D) terkonversi menjadi kawasan permukiman (lingkaran C). Ini secara logis bisa dipahami karena dalam sistem pasar, alih fungsi lahan berlangsung dari aktivitas yang menghasilkan nilai ekonomis lebih rendah ke aktivitas yang menghasilkan nilai ekonomis yang lebih tinggi.

\section{Alih Fungsi Lahan Pertanian di Kawasan Perkotaan Mangupura}

Proses terjadinya alih fungsi lahan pertanian, berkaitan erat dengan ekspansi atau perluasan kawasan perkotaan, pertumbuhan penduduk, perkembangan industri dan kegiatan pariwisata (Catur, 2010: 39). Alih fungsi lahan pertanian umumnya terjadi di kawasan perkotaan yang memiliki aksesibilitas, potensi wilayah, daya tarik dan faktor strategis tertentu. Lahan pertanian menjadi salah satu lahan yang sangat rentan mengalami perubahan pemanfaatan ruang, atau alih fungsi lahan menjadi kawasan terbangun. Hal ini benar adanya, terutama bagi lahan pertanian yang berlokasi ditengah-tengah kawasan perkotaan, memiliki topografi yang datar, dan telah dilengkapi dengan akses jalan yang lebar, serta didukung oleh ketersediaan sarana dan prasarana (Winoto, 2005: 8). Demikian pula halnya yang menjadi faktor penyebab alih fungsi lahan pertanian di Kawasan di Kabupaten Badung.

Tata guna lahan Kawasan Perkotaan Mangupura telah mengalami perubahan yang sangat signifikan. Hal ini bisa dilihat dari pemanfaatan lahan di tahun 2006 yang masih didominasi oleh sektor pertanian seluas 3.049,55 hektar, atau sekitar 85,02\% dari luas keseluruhan. Jika dijabarkan, 2.068,33 hektar atau 57,66\% area di tahun 2006 dimanfaatkan sebagai lahan persawahan, lahan untuk pertanian bukan sawah mencapai 981,22 hektar atau 27,35\%. Sedangkan, kawasan yang terbangun seluas 486,18 hektar atau sekitar 13,55\% dari luas keseluruhan. Namun data statistik untuk tahun 2015 menunjukan perubahan yang fundamental. Luas areal lahan pertanian telah berkurang 0,60\% atau sebanyak 21,63 hektar, dan tersisa 3.027,92 hektar atau sekitar 84,41\% dari luas keseluruhan, yang terdiri dari lahan pertanian sawah sebesar 2.055,52 hektar atau 57,30\% dan lahan pertanian bukan sawah yang mencapai 972,40 hektar atau 27,11\%. Sedangkan, kawasan terbangun mengalami peningkatan sebesar 17,88 hektar menjadi 504,06 hektar atau 14,05\% dari luas keseluruhan, seperti yang terlihat pada Tabel 2 . 
Tabel 2. Perubahan Tata Guna Lahan di Kawasan Perkotaan Mangupura

\begin{tabular}{|c|c|c|c|c|c|c|c|c|c|}
\hline \multirow[t]{3}{*}{ No } & \multirow{3}{*}{$\begin{array}{c}\text { Perubahan } \\
\text { Tata Guna } \\
\text { Lahan }\end{array}$} & \multicolumn{8}{|c|}{ Jenis Pemanfaatan dan Tata Guna Lahan } \\
\hline & & \multicolumn{2}{|c|}{$\begin{array}{c}\text { Lahan Pertanian } \\
\text { Sawah }\end{array}$} & \multicolumn{2}{|c|}{$\begin{array}{c}\text { Lahan Pertanian } \\
\text { Bukan Sawah }\end{array}$} & \multicolumn{2}{|c|}{$\begin{array}{l}\text { Rumah dan } \\
\text { Bangunan }\end{array}$} & \multicolumn{2}{|c|}{ Lainnya } \\
\hline & & $(\mathrm{Ha})$ & $(\%)$ & (Ha) & $(\%)$ & $(\mathrm{Ha})$ & $(\%)$ & (Ha) & $(\%)$ \\
\hline 1 & Th. 2006 & $2.068,33$ & 57,66 & 981,22 & 27,35 & 486,18 & 13,55 & 51,27 & 1,43 \\
\hline 2 & Th. 2007 & $2.066,97$ & 57,62 & 979,15 & 27,30 & 489,14 & 13,64 & 51,74 & 1,44 \\
\hline 3 & Th. 2008 & $2.064,21$ & 57,55 & 978,89 & 27,28 & 491,85 & 13,71 & 52,05 & 1,45 \\
\hline 4 & Th. 2009 & $2.063,56$ & 57,53 & 976,47 & 27,23 & 494,55 & 13,79 & 52,42 & 1,46 \\
\hline 5 & Th. 2010 & $2.061,44$ & 57,47 & 975,71 & 27,20 & 497,29 & 13,86 & 52,56 & 1,47 \\
\hline 6 & Th. 2011 & $2.060,71$ & 57,45 & 973,32 & 27,13 & 499,85 & 13,94 & 53,12 & 1,48 \\
\hline 7 & Th. 2012 & $2.059,31$ & 57,41 & 972,13 & 27,10 & 501,80 & 13,99 & 53,76 & 1,50 \\
\hline 8 & Th. 2013 & $2.058,47$ & 57,39 & 971,83 & 27,09 & 502,67 & 14,01 & 54,08 & 1,51 \\
\hline 9 & Th. 2014 & $2.057,87$ & 57,37 & 971,94 & 27,09 & 503,03 & 14,02 & 54,16 & 1,52 \\
\hline 10 & Th. 2015 & $2.055,52$ & 57,30 & 972,40 & 27,11 & 504,06 & 14,05 & 55,02 & 1,54 \\
\hline
\end{tabular}

Sumber: Badan Pusat Statistik Kabupaten Badung, Kecamatan Mengwi Dalam Angka, 2007-2016

Berdasarkan hasil observasi dan analisa data yang telah dilakukan, kegiatan alih fungsi lahan pertanian yang terjadi di Kawasan Perkotaan Mangupura mengalami peningkatan yang menonjol. Alih fungsi lahan pertanian tersebut terjadi hampir di semua desa dan kelurahan di Kawasan Perkotaan Mangupura, dengan pola persebaran yang gradual, acak, serta dengan luas lahan pertanian yang mengalami alih fungsi relatif kecil. Dengan menggunakan peta citra satelit, yang di-overlay dengan peta RTRW, dan hasil observasi lapangan, peneliti menganalisa lokasi terjadinya alih fungsi lahan pertanian di Kawasan Perkotaan Mangupura, dapat dilihat pada Gambar 3 serta deskripsi kegiatannya disajikan pada Tabel 3.

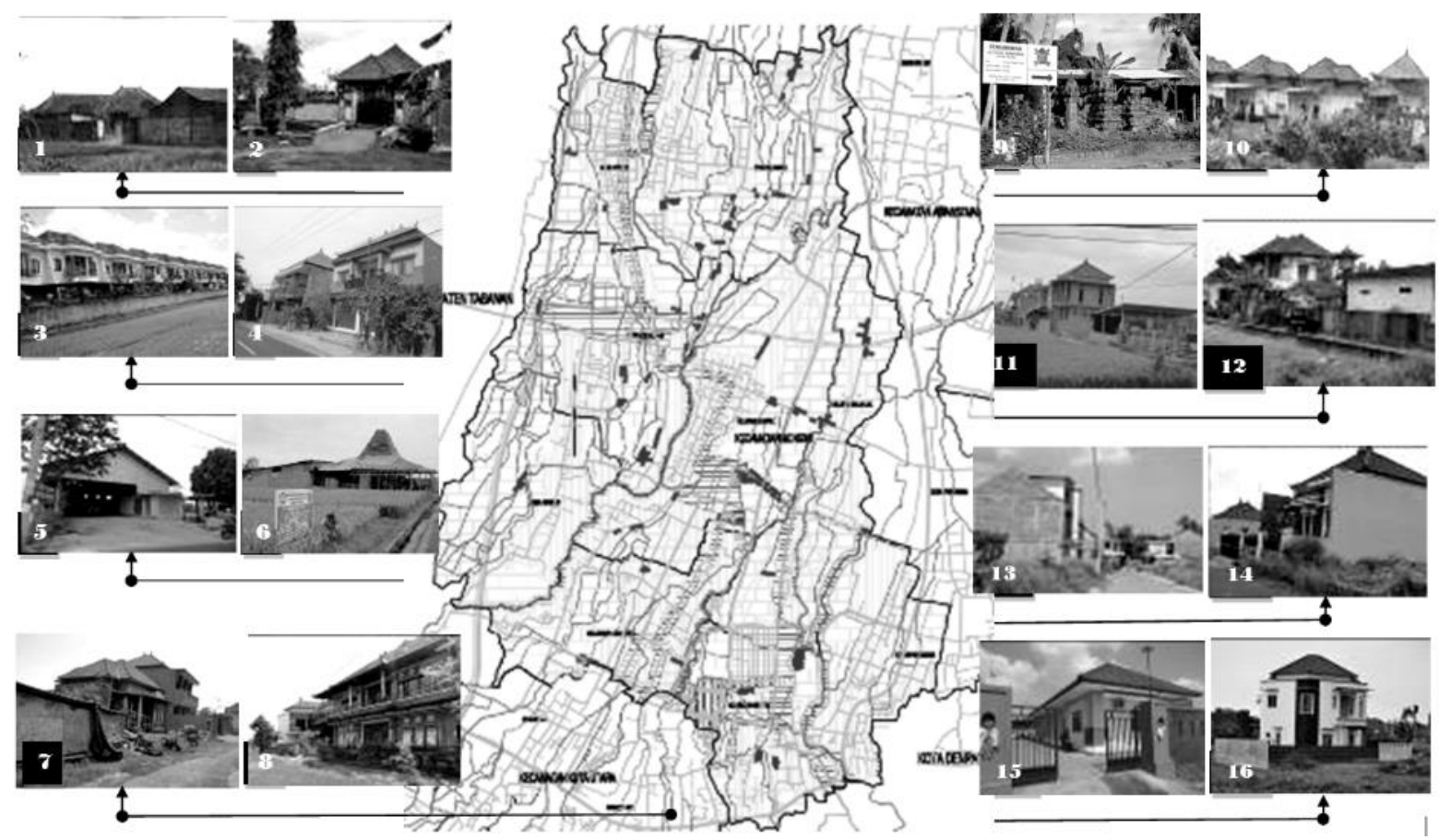

Gambar 3. Peta Lokasi Alih Fungsi Lahan Pertanian di Kawasan Perkotaan Mangupura Sumber: Penulis, 2017 
Tabel 3. Kegiatan Alih Fungsi Lahan Pertanian di Kawasan Perkotaan Mangupura

\begin{tabular}{|c|c|c|c|c|c|c|c|}
\hline \multirow{2}{*}{$\begin{array}{l}\text { No. } \\
\text { Studi } \\
\text { Kasus }\end{array}$} & \multicolumn{2}{|c|}{ Peruntukan Awal } & \multicolumn{2}{|c|}{ Peruntukan Sekarang } & \multirow{2}{*}{$\begin{array}{c}\text { Periode } \\
\text { Perubahan } \\
\text { Pemanfaatan }\end{array}$} & \multirow{2}{*}{$\begin{array}{l}\text { Perizinan } \\
\text { (IMB) }\end{array}$} & \multirow[t]{2}{*}{ Kategori } \\
\hline & $\begin{array}{l}\text { Pemanfaatan } \\
\text { Lahan }\end{array}$ & $\begin{array}{c}\text { Zonasi } \\
\text { (RDTR) }\end{array}$ & $\begin{array}{l}\text { Pemanfaatan } \\
\text { Lahan }\end{array}$ & $\begin{array}{c}\begin{array}{c}\text { Peraturan } \\
\text { (RTRW) }\end{array} \\
\text { (RT) }\end{array}$ & & & \\
\hline 1 & Sawah & $\begin{array}{l}\text { Kawasan } \\
\text { Pertanian }\end{array}$ & Rumah Tinggal & $\begin{array}{l}\text { Kawasan } \\
\text { Pertanian }\end{array}$ & Tahun 2006 & Tidak & $\begin{array}{c}\text { Alih Fungsi } \\
\text { Lahan Pertanian }\end{array}$ \\
\hline 2 & Sawah & $\begin{array}{l}\text { Kawasan } \\
\text { Pertanian }\end{array}$ & Rumah Tinggal & $\begin{array}{l}\text { Kawasan } \\
\text { Pertanian }\end{array}$ & Tahun 2011 & Tidak & $\begin{array}{c}\text { Alih Fungsi } \\
\text { Lahan Pertanian }\end{array}$ \\
\hline 3 & Sawah & $\begin{array}{l}\text { Kawasan } \\
\text { Pertanian }\end{array}$ & Rumah Tinggal & $\begin{array}{l}\text { Kawasan } \\
\text { Pertanian }\end{array}$ & Tahun 2013 & Tidak & $\begin{array}{c}\text { Alih Fungsi } \\
\text { Lahan Pertanian }\end{array}$ \\
\hline 4 & $\begin{array}{l}\text { Kebun / } \\
\text { Ladang }\end{array}$ & $\begin{array}{l}\text { Kawasan } \\
\text { Pertanian }\end{array}$ & Toko Bangunan & $\begin{array}{l}\text { Kawasan } \\
\text { Pertanian }\end{array}$ & Tahun 2010 & Tidak & $\begin{array}{c}\text { Alih Fungsi } \\
\text { Lahan Pertanian }\end{array}$ \\
\hline 5 & Sawah & $\begin{array}{l}\text { Kawasan } \\
\text { Pertanian }\end{array}$ & Gudang Industri & $\begin{array}{l}\text { Kawasan } \\
\text { Pertanian }\end{array}$ & Tahun 2008 & Tidak & $\begin{array}{c}\text { Alih Fungsi } \\
\text { Lahan Pertanian }\end{array}$ \\
\hline 6 & Sawah & $\begin{array}{l}\text { Kawasan } \\
\text { Pertanian }\end{array}$ & Warung Makan & $\begin{array}{l}\text { Kawasan } \\
\text { Pertanian }\end{array}$ & Tahun 2014 & Tidak & $\begin{array}{c}\text { Alih Fungsi } \\
\text { Lahan Pertanian }\end{array}$ \\
\hline 7 & Sawah & $\begin{array}{l}\text { Kawasan } \\
\text { Pertanian }\end{array}$ & Rumah Tinggal & $\begin{array}{l}\text { Kawasan } \\
\text { Pertanian }\end{array}$ & Tahun 2014 & Tidak & $\begin{array}{c}\text { Alih Fungsi } \\
\text { Lahan Pertanian }\end{array}$ \\
\hline 8 & $\begin{array}{l}\text { Kebun / } \\
\text { Ladang }\end{array}$ & $\begin{array}{l}\text { Kawasan } \\
\text { Pertanian }\end{array}$ & Pertokoan & $\begin{array}{l}\text { Kawasan } \\
\text { Pertanian }\end{array}$ & Tahun 2007 & Tidak & $\begin{array}{c}\text { Alih Fungsi } \\
\text { Lahan Pertanian }\end{array}$ \\
\hline 9 & $\begin{array}{l}\text { Kebun / } \\
\text { Ladang }\end{array}$ & $\begin{array}{l}\text { Kawasan } \\
\text { Pertanian }\end{array}$ & $\begin{array}{l}\text { Industri } \\
\text { Percetakan }\end{array}$ & $\begin{array}{l}\text { Kawasan } \\
\text { Pertanian }\end{array}$ & Tahun 2006 & Tidak & $\begin{array}{c}\text { Alih Fungsi } \\
\text { Lahan Pertanian }\end{array}$ \\
\hline 10 & Sawah & $\begin{array}{l}\text { Kawasan } \\
\text { Pertanian }\end{array}$ & Rumah Tinggal & $\begin{array}{l}\text { Kawasan } \\
\text { Pertanian }\end{array}$ & Tahun 2015 & Tidak & $\begin{array}{c}\text { Alih Fungsi } \\
\text { Lahan Pertanian }\end{array}$ \\
\hline 11 & Sawah & $\begin{array}{l}\text { Kawasan } \\
\text { Pertanian }\end{array}$ & Rumah Tinggal & $\begin{array}{l}\text { Kawasan } \\
\text { Pertanian }\end{array}$ & Tahun 2014 & Tidak & $\begin{array}{c}\text { Alih Fungsi } \\
\text { Lahan Pertanian }\end{array}$ \\
\hline 12 & Sawah & $\begin{array}{l}\text { Kawasan } \\
\text { Pertanian }\end{array}$ & Rumah Tinggal & $\begin{array}{l}\text { Kawasan } \\
\text { Pertanian }\end{array}$ & Tahun 2004 & Tidak & $\begin{array}{c}\text { Alih Fungsi } \\
\text { Lahan Pertanian }\end{array}$ \\
\hline 13 & Sawah & $\begin{array}{l}\text { Kawasan } \\
\text { Pertanian }\end{array}$ & Rumah Tinggal & $\begin{array}{l}\text { Kawasan } \\
\text { Pertanian }\end{array}$ & Tahun 2016 & Tidak & $\begin{array}{c}\text { Alih Fungsi } \\
\text { Lahan Pertanian }\end{array}$ \\
\hline 14 & $\begin{array}{l}\text { Kebun / } \\
\text { Ladang }\end{array}$ & $\begin{array}{l}\text { Kawasan } \\
\text { Pertanian }\end{array}$ & Rumah Tinggal & $\begin{array}{l}\text { Kawasan } \\
\text { Pertanian }\end{array}$ & Tahun 2011 & Tidak & $\begin{array}{c}\text { Alih Fungsi } \\
\text { Lahan Pertanian }\end{array}$ \\
\hline 15 & Sawah & $\begin{array}{l}\text { Kawasan } \\
\text { Pertanian }\end{array}$ & Rumah Kos & $\begin{array}{l}\text { Kawasan } \\
\text { Pertanian }\end{array}$ & Tahun 2016 & Tidak & $\begin{array}{c}\text { Alih Fungsi } \\
\text { Lahan Pertanian }\end{array}$ \\
\hline 16 & Sawah & $\begin{array}{l}\text { Kawasan } \\
\text { Pertanian }\end{array}$ & Pertokoan & $\begin{array}{l}\text { Kawasan } \\
\text { Pertanian }\end{array}$ & Tahun 2009 & Tidak & $\begin{array}{c}\text { Alih Fungsi } \\
\text { Lahan Pertanian }\end{array}$ \\
\hline
\end{tabular}

Sumber: Penulis, 2017

\section{Faktor Penyebab Alih Fungsi Lahan Pertanian di Kawasan Perkotaan Mangupura}

Yunus (2012: 26) berpendapat jika perkembangan kehidupan kota, dapat dilihat dari penambahan dan pengurangan jumlah bangunan, penambahan dan pengurangan fungsi dalam pemanfaatan lahan, perubahan jumlah dan komposisi penduduk. Perubahan aspekaspek kehidupan ini telah memperkaya sifat dinamis dari sebuah kawasan perkotaaan. Charles O. Colby, 1933 dalam (Yunus, 2012: 177) pertama kali mencetuskan idenya tentang kekuatan-kekuatan dinamis yang mempengaruhi penggunaan lahan di kawasan perkotaan. Colby mengatakan bahwa proses perluasan kota yang semakin progresif belakangan ini telah mempengaruhi struktur tata guna lahan perkotaan. Ada dua kekuatan dasar yang menentukan tata guna lahan di kota, yaitu daya sentrifugal dan sentripetal. Kekuatan sentrifugal (centrifugal force) merupakan daya dinamis yang memicu terjadinya pergerakan penduduk, dan fungsi-fungsi perkotaan dari bagian dalam menuju ke bagian luar suatu kawasan perkotaan. Kekuatan-kekuatan sentrifugal merupakan kombinasi dari faktor pendorong (push factors) pada bagian dalam, dan faktor penarik (pull factors) pada bagian luar. 
Kekuatan sentrifugal dapat lebih lanjut dirinci menjadi enam jenis kekuatan, termasuk: kekuatan keruangan (spatial forces), kekuatan site (site forces), kekuatan situasional (situational forces), kekuatan evaluasi sosial (the forces of sosial evaluation), kekuatan status dan organisasi penempatan (the forces of status and organization of occupance), dan kekuatan persamaan harkat kemanusiaan (human equation forces). Sedangkan kekuatan sentripetal (centripetal force) merupakan kombinasi dari kekuatan pendorong pada bagian luar, dan kekuatan menarik pada bagian dalam, yang dapat dibedakan menjadi lima jenis kekuatan antara lain, kekuatan site (site forces), kekuatan kemudahan fungsional (functional convenience forces), kekuatan magnetisme fungsional (magnetism functional forces), kekuatan prestise fungsional (functional prestise forces), dan kekuatan persamaan kemanusiaan (human equation forces).

Lebih lanjut dipaparkan, terdapat tiga faktor penting yang menyebabkan terjadinya alih fungsi lahan pertanian (Lestari, 2010: 14), termasuk: a) kekuatan eksternal yaitu faktor yang disebabkan oleh adanya dinamika perkembangan kawasan perkotaan, peningkatan kondisi demografi atau kependudukan, maupun pertumbuhan ekonomi; b) kekuatan internal, merupakan faktor kondisi sosial ekonomi petani yang disebabkan oleh tekanan ekonomi, sehingga banyak petani menjual lahan pertanian untuk memenuhi kebutuhan hidup; dan c) aspek kebijakan, yaitu faktor regulasi dan peraturan yang dikeluarkan oleh pemerintah yang berkaitan dengan penataan ruang. Kelemahan pada faktor kebijakan terutama terkait dengan masalah kekuatan produk hukum, instansi penegak hukum, akurasi data yang masih kurang, dan rendahnya sanksi terhadap pelanggaran pemanfaatan ruang. Dengan mempertimbangkan pendekatan yang disampaikan oleh Charles O. Colby dan Lestari, serta dengan didasari oleh hasil wawancara yang dilakukan dengan 32 orang narasumber yang telah dipilih melalui pendekatan purposive sampling, maka faktor-faktor pemicu terjadinya alih fungsi lahan di Kawasan Perkotaan Mangupura dapat diklasifikasikan ke dalam empat (4) kelompok. Pengelompokan ini bisa dilihat pada Tabel 4.

Tabel 4. Hasil Wawancara Mengenai Faktor Penyebab Alih Fungsi Lahan Pertanian

\begin{tabular}{|c|c|c|c|c|c|c|c|c|c|c|c|}
\hline \multirow[t]{2}{*}{ Narasumber } & \multicolumn{3}{|c|}{ Sosial } & \multicolumn{2}{|c|}{ Ekonomi } & \multicolumn{3}{|c|}{ Lingkungan } & \multicolumn{3}{|c|}{ Regulasi } \\
\hline & 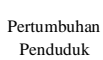 & $\begin{array}{c}\text { Sosial } \\
\text { Budaya } \\
\text { Buts }\end{array}$ & $\begin{array}{c}\text { Minat } \\
\text { Bertani }\end{array}$ & $\begin{array}{c}\text { Nilai } \\
\text { Investasi }\end{array}$ & $\begin{array}{l}\text { Desakan } \\
\text { Ekonomi }\end{array}$ & $\begin{array}{c}\text { Kondisi } \\
\text { Lahan }\end{array}$ & $\begin{array}{l}\text { Lokasi } \\
\text { Strategis }\end{array}$ & $\begin{array}{l}\text { Sarana \& } \\
\text { Prasarana }\end{array}$ & $\begin{array}{c}\text { Penegakan } \\
\text { Hukum }\end{array}$ & 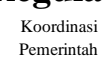 & $\begin{array}{c}\text { Paham } \\
\text { Peraturan }\end{array}$ \\
\hline $\begin{array}{l}\text { Penduduk } \\
\text { Pendatang }\end{array}$ & 0 & 2 & 0 & 8 & I & 3 & 8 & 7 & 7 & 0 & 6 \\
\hline $\begin{array}{l}\text { Penduduk Asli / } \\
\text { Pemilik Lahan }\end{array}$ & 4 & 1 & 5 & 1 & 6 & 2 & 1 & 3 & 5 & 0 & 0 \\
\hline $\begin{array}{c}\text { Tokoh } \\
\text { Masyarakat }\end{array}$ & 5 & 0 & 2 & 0 & 5 & 3 & 1 & 4 & 3 & 0 & 0 \\
\hline $\begin{array}{c}\text { Instansi } \\
\text { Pemerintah }\end{array}$ & 9 & 2 & 4 & 4 & 6 & 3 & 1 & 9 & 5 & 2 & 1 \\
\hline $\begin{array}{l}\text { Developer / } \\
\text { Pengembang }\end{array}$ & 2 & 1 & 1 & 0 & 2 & 1 & 1 & 2 & 2 & 0 & 0 \\
\hline $\begin{array}{l}\text { Pengamat } \\
\text { Tata Ruang }\end{array}$ & 1 & 1 & 0 & 0 & 1 & 0 & 1 & 1 & 1 & 0 & 1 \\
\hline Jumlah & 21 & 7 & 12 & 13 & 21 & 12 & 13 & 26 & 23 & 2 & 8 \\
\hline
\end{tabular}

Sumber: Penulis, 2017

Pengelompokan di atas juga mempertimbangkan prinsip-prinsip pembangunan berkelanjutan, yang dimaknai sebagai kegiatan serta usaha untuk memenuhi kebutuhan 
generasi saat ini, tanpa mengurangi kemampuan generasi yang akan datang dalam memenuhi kebutuhannya (Sudarmaji, 2008: 57). Pembangunan berkelanjutan mencakup tiga aspek yang tidak terpisahkan satu sama lain, yaitu pembangunan ekonomi, pembangunan sosial, dan perlindungan terhadap lingkungan. Hubungan antara ekonomi dan sosial diharapkan dapat menciptakan hubungan yang adil (equitable). Hubungan antara ekonomi dan lingkungan diharapkan dapat terus berjalan (viable). Sedangkan hubungan antara sosial dan lingkungan bertujuan bisa terus dipertahankan (bearable). Ketiga aspek yaitu aspek ekonomi, sosial dan lingkungan akan menciptakan kondisi berkelanjutan (sustainable). Hubungan antara ketiga aspek tersebut dapat dilihat pada Gambar 4 berikut.

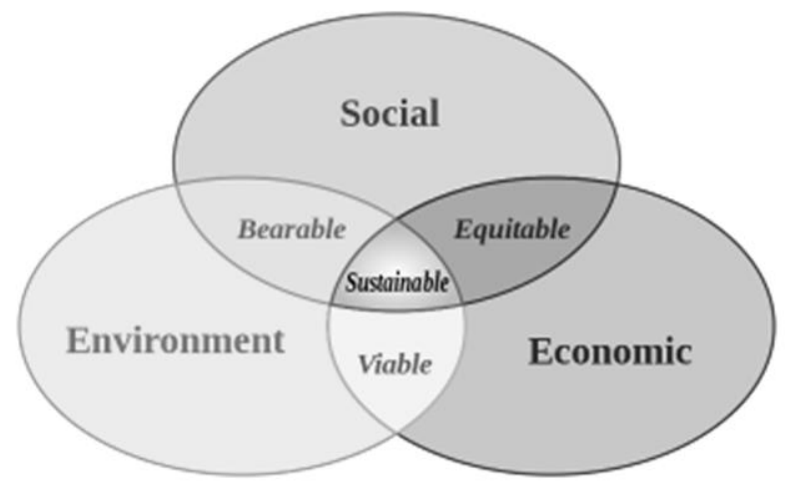

Gambar 4. Diagram Pembangunan Berkelanjutan Sumber: Sudarmaji, 2008

Saroso (2002: 14-15) mengopinikan bahwa pembangunan kawasan perkotaan yang berkelanjutan wajib merangkul elemen dasar pembangunan, yaitu: sosial dan kultural (socially and culturally suitable and accountable); politik (politically acceptable), kelayakan ekonomis (economically feasible), dan bisa dipertanggungjawabkan dari segi lingkungan (environmentally sound and sustainable). Integrasi antara keempat komponen ini yang dilaksanakan secara konsisten dan konsekuen, akan mengantarkan pembangunan kawasan perkotaan yang berkelanjutan dan berwawasan lingkungan. Berikut ini dipaparkan lebih detail faktor-faktor pemicu yang telah mendorong terjadinya alih fungsi lahan pertanian di Kawasan Perkotaan Mangupura Kabupaten Badung.

\section{a. Aspek Sosial}

Aspek sosial yang mempengaruhi alih fungsi lahan pertanian di Kawasan Perkotaan Mangupura Kabupaten Badung, meliputi:

\section{Pertumbuhan Penduduk}

Seperti yang telah diungkapkan oleh Colby, 1933 dalam (Yunus, 2012: 177-178) bahwa, perkembangan suatu kota bersifat dinamis, termasuk dalam konteks penggunaan lahannya. Colby lebih lanjut mengungkapkan beberapa kekuatan yang mempengaruhi dinamika perkembangan ini, termasuk perubahan jumlah penduduk, perubahan tuntutan masyarakat, penambahan dan pengurangan bangunan, perubahan nilai-nilai kehidupan, serta aspek-aspek kehidupan masyarakat. Berdasarkan data yang diperoleh, pertumbuhan jumlah penduduk di Kawasan Perkotaan Mangupura dalam sepuluh tahun (2006-2015) telah secara kontinyu mengalami peningkatan, baik yang diakibatkan oleh tingkat kelahiran maupun migrasi populasi. 
Jumlah penduduk di Kawasan Perkotaan Mangupura di tahun 2006 mencapai 106.526 orang, dengan tingkat kepadatan rata-rata 29,69 jiwa $/ \mathrm{km}^{2}$. Selanjutnya, di tahun 2015, jumlah penduduk mencapai 115.177 orang, dengan tingkat kepadatan rata-rata mencapai 32,11 jiwa/ $/ \mathrm{km}^{2}$. Hal ini menunjukkan bahwa laju pertumbuhan penduduk di Kawasan Perkotaan Mangupura tergolong tinggi. Jika diinterpretasikan, dalam sepuluh tahun terakhir jumlah penduduk telah bertambah sebanyak 8.651 jiwa, dengan laju pertumbuhan rata-rata sebesar 2,66\% per tahun. Detail pertumbuhan penduduk ini bisa dilihat pada Tabel 5.

Tabel 5. Pertumbuhan Penduduk di Kawasan Perkotaan Mangupura

\begin{tabular}{|c|c|c|c|c|c|}
\hline \multirow[t]{2}{*}{ No. } & \multirow{2}{*}{$\begin{array}{l}\text { Perubahan } \\
\text { Kepadatan } \\
\text { Penduduk }\end{array}$} & \multicolumn{2}{|c|}{ Penduduk } & \multirow[t]{2}{*}{ Jumlah } & \multirow{2}{*}{$\begin{array}{c}\text { Kepadatan } \\
\text { per } \mathbf{K m}^{2}\end{array}$} \\
\hline & & Laki & Perempuan & & \\
\hline 1 & Th. 2006 & 52.872 & 53.654 & 106.526 & 29,69 \\
\hline 2 & Th. 2007 & 53.055 & 53.873 & 106.928 & 29,81 \\
\hline 3 & Th. 2008 & 53.382 & 54.157 & 107.539 & 29,98 \\
\hline 4 & Th. 2009 & 53.753 & 54.716 & 108.469 & 30,24 \\
\hline 5 & Th. 2010 & 54.012 & 54.894 & 108.906 & 30,36 \\
\hline 6 & Th. 2011 & 54.758 & 55.830 & 110.588 & 30,83 \\
\hline 7 & Th. 2012 & 56.078 & 56.816 & 112.894 & 31,47 \\
\hline 8 & Th. 2013 & 57.202 & 57.196 & 114.398 & 31,89 \\
\hline 9 & Th. 2014 & 57.233 & 57.807 & 115.040 & 32,07 \\
\hline 10 & Th. 2015 & 57.278 & 57.899 & 115.177 & 32,11 \\
\hline
\end{tabular}

Sumber: Badan Pusat Statistik Kabupaten Badung, Kecamatan Mengwi Dalam Angka, 2007-2016

Semakin tingginya laju pertumbuhan penduduk akan meningkatkan kebutuhan terhadap ruang atau lahan, baik yang didedikasikan guna mewadahi kepentingan akan tempat tinggal, kegiatan komersial, industri, pelayanan publik, infrastruktur fisik, serta kegiatan terkait interaksi sosial di masyarakat. Kondisi ini akan secara langsung berimplikasi terhadap perluasan kawasan terbangun, di beberapa lokasi yang dipandang strategis dan tepat untuk kepentingan-kepentingan tersebut. Pertumbuhan penduduk di Kawasan Perkotaan Mangupura yang relatif tinggi, seperti yang telah dijelaskan di atas, selain telah mengakibatkan perluasan kawasan terbangun juga telah memicu terjadinya penumpukan kegiatan pada beberapa wilayah yang menjadi pusat aktivitas. Perluasan ini seringkali terjadinya di atas lahan-lahan yang mewadahi fungsi agraris (lihat Gambar 3). Bahkan kondisi ini juga terjadi di atas lahan agraris yang menurut tata ruang kota dizonasikan sebagai zona ruang terbuka hijau. Dalam kenyataan di lapangan, ruang-ruang ini telah dikonversi menjadi kawasan terbangun. Sirkumstansi ini menunjukkan telah terjadinya pelanggaran terhadap peraturan tata ruang yang berlaku.

\section{Sosial Budaya}

Faktor sosial budaya yang telah menjadi pemicu terjadinya alih fungsi lahan pertanian dalam konteks ini, adalah keberadaan sistem pembagian hak waris yang berlaku di masyarakat. Seperti diketahui bersama, lahan pertanian merupakan salah satu harta warisan yang memiliki nilai strategis. Warisan ini akan menjadi pemicu terjadinya alih fungsi lahan di Kawasan Perkotaan Mangupura Kabupaten Badung, ketika lahan (nilai ekonomisnya/pemanfaatannya) harus dibagi-bagi di antara para pewaris menjadi bagian 
yang lebih kecil. Tidak jarang ditemui kasus, dimana hasil pembagian warisan ini memunculkan plot-plot lahan, dengan skala fisik yang tidak memungkinkan (secara teknis dan ekonomis) untuk dimanfaatkan sebagai lahan pertanian. Solusi yang diambil adalah jualbeli lahan yang kemudian akan mengantar pada perubahan wujud pemanfaatannya oleh si pemilik baru.

Hal ini sesuai dengan pendapat yang dikemukakan oleh Mufaganti, 1999 dalam (Pambudi, 2008: 51), yang menyatakan bahwa sistem pembagian waris akan cenderung mengakibatkan semakin kecilnya penguasaan terhadap lahan pertanian, dan akan mempengaruhi terjadinya alih fungsi lahan pertanian ke non pertanian. Kondisi ini sangat lumrah terjadi di Kawasan Perkotaan Mangupura. Kegiatan alih fungsi lahan pertanian sebagian besar diakibatkan oleh adanya masyarakat yang menjual hak warisnya atas lahan kepada pihak pembeli maupun pihak pengembang/developer. Para petani yang diinterview dalam studi ini mengatakan bahwa, luasan lahan yang kecil tidak akan produktif untuk dimanfaatkan sebagai lahan pertanian. Meskipun dipaksakan, nantinya akan mempengaruhi penghasilan petani. Perbandingan biaya produksi dan hasil panen tidak akan bisa memenuhi kebutuhan dasar para petani dalam mempertahankan hidup. Hal inilah yang menjadi pemicu alih hak atas lahan yang kemudian memicu alih fungsi lahan pertanian.

\section{Rendahnya Ketertarikan Generasi Muda untuk Menggeluti Bidang Pertanian}

Semakin kecilnya minat generasi muda untuk menggeluti pekerjaan di bidang pertanian, dapat dilihat dari perubahan mata pencaharian penduduk di Kawasan Perkotaan Mangupura. Data statistik untuk sepuluh tahun terakhir (2006-2015) menunjukan bahwa, telah terjadi perubahan yang signifikan terkait pekerjaan yang digeluti penduduk di kota ini. Sesuai dengan data pada Tabel 6., di tahun 2006, ekonomi di Kawasan ini didominasi oleh sektor pertanian. Sebanyak 20.028 jiwa, atau lebih dari 51,87\% penduduk Kota Mangupura bekerja di sektor pertanian. Sisanya, 18.581 jiwa, atau 48,13\% dari keseluruhan penduduk produktif bekerja di sektor non primer atau di luar kegiatan pertanian.

Tabel 6. Perubahan Mata Pencaharian Penduduk di Kawasan Perkotaan Mangupura

\begin{tabular}{|c|c|c|c|c|c|c|c|}
\hline \multirow[t]{2}{*}{ No. } & \multirow{2}{*}{$\begin{array}{c}\text { Perubahan } \\
\text { Mata } \\
\text { Pencaharian }\end{array}$} & \multicolumn{6}{|c|}{ Jenis Mata Pencaharian } \\
\hline & & Pertanian & Perdagangan & Industri & $\begin{array}{l}\text { Angkutan, } \\
\text { Komunikasi }\end{array}$ & $\begin{array}{c}\text { Bank, } \\
\text { Lembaga } \\
\text { Keuangan }\end{array}$ & $\begin{array}{c}\text { Pemerintahan, } \\
\text { Jasa-jasa \& } \\
\text { Lainnya }\end{array}$ \\
\hline 1 & Th. 2006 & 20.028 & 5.806 & 2.602 & 2.897 & 1.838 & 5.438 \\
\hline 2 & Th. 2007 & 19.892 & 5.997 & 2.698 & 2.924 & 1.846 & 5.471 \\
\hline 3 & Th. 2008 & 19.778 & 6.016 & 2.707 & 2.902 & 1.853 & 5.455 \\
\hline 4 & Th. 2009 & 19.563 & 6.078 & 2.744 & 2.885 & 2.063 & 5.371 \\
\hline 5 & Th. 2010 & 19.433 & 5.918 & 2.671 & 2.735 & 2.035 & 5.344 \\
\hline 6 & Th. 2011 & 19.120 & 6.043 & 2.723 & 2.653 & 2.028 & 5.691 \\
\hline 7 & Th. 2012 & 18.631 & 6.085 & 2.237 & 2.109 & 2.036 & 5.827 \\
\hline 8 & Th. 2013 & 17.071 & 6.589 & 2.464 & 2.146 & 2.184 & 8.133 \\
\hline 9 & Th. 2014 & 16.906 & 6.639 & 2.481 & 2.127 & 2.214 & 8.168 \\
\hline 10 & Th. 2015 & 16.762 & 6.702 & 2.513 & 2.134 & 2.287 & 8.314 \\
\hline
\end{tabular}

Sumber: Badan Pusat Statistik Kabupaten Badung, Kecamatan Mengwi Dalam Angka, 2007-2016 
Namun seiring waktu, jumlah penduduk yang bermatapencaharian di sektor pertanian mengalami penurunan. Di tahun 2015 penduduk yang bekerja di sektor primer ini tercatat sejumlah 16.762 jiwa atau 43,32\%, dan penduduk yang bekerja di sektor non primer/non pertanian berjumlah 21.935 jiwa atau $56,68 \%$ dari keseluruhan jenis mata pencaharian penduduk. Ini berarti telah terjadi penurunan jumlah petani sebanyak 3.266 jiwa atau $8,55 \%$, sedangkan jumlah pekerja di sektor non primer mengalami peningkatan sebesar 3.354 jiwa. Adapun sektor di luar pertanian yang digeluti penduduk termasuk bidang perdagangan dan jasa, pemerintahan, industri, keuangan dan perbankan.

Kondisi tersebut tidak bisa dilepaskan dari adanya perubahan pandangan serta pola hidup di masyarakat. Pola kehidupan agraris telah secara lambat laun bergeser ke pola hidup nonagraris. Kehidupan agraris sering dikonotasikan sebagai representasi kehidupan pedesaan, sedangkan non agraris dikonotasikan sebagai kehidupan urban sebuah kondisi yang diidamidamkan oleh para generasi muda, termasuk generasi penerus yang bermukim di Kawasan Mangupura Kabupaten Badung. Pergeseran pandangan ini secara langsung mengurangi daya tarik sektor primer atau pertanian, dan pada saat yang sama menjadikan sektor non-primer (pertanian sebagai bidang yang lukratif), terutama bagi generasi muda. Secara ekonomis, kondisi ini didukung oleh kenyataan jika sektor pertanian belum bisa menjanjikan kepastian akan pemasukan, karena ketergantungannya terhadap beragam kondisi eksternal (cuaca, hama, dan kebijakan eksport/import). Di sisi lain, sektor non-pertanian seringkali menawarkan kepastian akan kontribusi ekonomis, sehingga generasi muda dapat menyusun rencana dalam menyikapi beragam kepentingan dalam pemenuhan kebutuhan hidup.

Penurunan minat generasi muda untuk bekerja di sektor pertanian telah disampaikan oleh Herlina (2002: 89), yang menyatakan bahwa saat ini generasi muda cenderung memilih untuk menggantungkan hidupnya kepada sektor non-pertanian yang ada di perkotaan untuk memperoleh penghasilan, kekayaan, dan kejayaan. Alasan mendasar yang mendorong mereka untuk mengambil pilihan ini, adalah rendahnya tingkat upah yang diterima jika bekerja di sektor pertanian, dibandingkan dengan upah yang diperoleh dari bekerja di sektor non-pertanian. Sehingga sektor pertanian akhirnya didominasi oleh generasi tua, yang seringkali memiliki produktivitas yang lebih rendah dibandingkan dengan generasi muda. Mereka ini juga kurang responsif terhadap perubahan, terutama dalam mengakomodasi perubahan, sebagai akibat dari terjadinya kemajuan di bidang ilmu pengetahuan serta teknologi, yang aplikabel untuk diterapkan di bidang pertanian.

\section{b. Aspek Ekonomi}

Hasil studi menunjukan bahwa aspek ekonomi yang telah memicu terjdinya alih fungsi lahan pertanian di Kawasan Perkotaan Mangupura Kabupaten Badung, merupakan kumpulan faktor-faktor penyebab yang ditinjau dari karakteristik ekonomi lahan, dan kondisi ekonomi masyarakat, yang meliputi:

\section{Diperlakukannya Lahan sebagai Alat Investasi}

Pertumbuhan kawasan perkotaan, berimplikasi terhadap muncul dan meningkatnya persaingan dalam penguasaan lahan, untuk mewadahi beragam kebutuhan yang 
dimunculkan oleh beragam sektor pembangunan. Yang sering terjadi adalah adanya ketimpangan antara permintaan dan ketersediaan lahan, mengingat peningkatan kebutuhan tidak akan pernah diiringi dengan peningkatan suplai. Seperti telah dipahami bersama, lahan merupakan sumber daya pendukung produksi yang terbatas (finite), dan tidak bisa diperbaharui. Pernyataan ini mungkin akan diruntuhkan oleh argumentasi, bahwa kegiatan reklamasi akan mampu menyediakan berhektar-hektar lahan baru. Namun menyadari fenomena pemanasan global dan peningkatan level air laut yang mengkhawatirkan belakangan ini, kita dipaksa untuk mempertanyakan relevansi kegiatan reklamasi, serta memaksa kita untuk memandang eksistensi lahan, yang alam telah sediakan sebagai sumber daya yang langka. Secara konsekuensi, kondisi ini telah memicu terjadinya eskalasi nilai ekonomis lahan dimana-mana.

Peningkatan harga lahan di kawasan perkotaan telah mendorong pemilik lahan pertanian untuk menjual atau mengalihfungsikan pemanfaatannya, dari fungsi pertanian menjadi nonpertanian. Secara ekonomis keputusan ini diambil, karena dipandang akan memberi kontribusi finansial yang lebih tinggi. Dengan kata lain pemanfaatan lahan untuk kegiatan agraris kurang kompetitif, jika dibandingkan dengan lahan yang sama dimanfaatkan sebagai wadah kegiatan non-agraris. Ini terjadi khususnya untuk lahan-lahan yang secara geografis terletak pada lokasi yang berada dalam radius pusat kota. Di dalam penelitian ini, semakin dekat lokasi sebidang lahan dengan pusat kota, dalam hal ini Kelurahan Sempidi sebagai Central Business District (CBD), akan secara langsung meningkatkan nilai ekonomisnya. Namun perlu juga disadari disini bahwa, faktor persepsi masyarakat juga memiliki kontribusi penting dalam hal tersebut. Pemanfaat lahan memiliki ketertarikan tinggi untuk berkerumun, berebut lahan, dan beraktivitas di pusat kota jika dibandingkan dengan di luar radius kawasan perkotaan.

Sebagai konsekuensi, kondisi ini telah meningkatkan harga lahan di dalam kota. Kejadian ini berbanding lurus dengan pendapat yang dikemukakan oleh Von Thunen dalam (Hermit, 2009:98) yang mengatakan bahwa harga tanah ditentukan oleh panjang jarak secara geografis lokasi tanah tersebut terhadap pusat kegiatan kota atau Central Business District (CBD). Semakin dekat lokasi tanah terhadap CBD, maka semakin tinggi pula harga dan permintaan terhadap tanah tersebut. Sebaliknya, semakin jauh lokasi tanah terhadap CBD, maka semakin rendah pula harga dan permintaan terhadap tanah tersebut. Selain itu, tingginya nilai ekonomis lahan di Kawasan Perkotaan Mangupura juga disebabkan oleh pesatnya pembangunan perumahan dan intensifnya kegiatan jual beli lahan. Reilly dan Brown, 1982 dalam (Widoatmojo, 2007: 69) menjelaskan bahwa bisnis di bidang properti terutama jual beli rumah dan transaksi tanah, merupakan investasi yang paling menguntungkan. Aktivitas ini tidak dipengaruhi oleh inflasi yang terjadi. Alasan inilah yang mendasari maraknya pasar lahan, khususnya untuk lahan-lahan yang berada di lokasi-lokasi strategis. Jadi, lahan sebagai alat investasi secara langsung berimplikasi pada semakin maraknya pengalihan hak atas lahan dari petani ke para pemilik modal, yang seringkali akan mengalihfungsikan pemanfaatan lahan dari pertanian ke wujud pemanfaatan lahan, yang mampu memberi kontribusi keuntungan yang jauh lebih tinggi. 


\section{Keterdesakan Ekonomi Petani}

Keterdesakan ekonomi yang dialami, terutama oleh petani dan pemilik lahan, secara tidak langsung mengakibatkan terjadinya alih fungsi lahan, baik yang dilakukan oleh pemilik lahan itu sendiri, maupun melalui proses jual beli kepada pihak lain. Semakin tingginya biaya hidup, dan tumbuhnya budaya konsumtif, budaya instant, cepat, serta menguntungkan secara ekonomis financial, telah menjadi pemicu keinginan pemilik lahan untuk mengalihfungsikan lahan pertanian yang dimiliknya. Tekanan ekonomi akan sangat dirasakan ketika terjadi ketimpangan pendapatan yang diperoleh dari hasil panen dengan pengeluaran yang semakin membumbung. Peningkatan kebutuhan finansial untuk menutupi biaya pendidikan anak, kesehatan keluarga, dan pemenuhan kebutuhan sehari-hari, menambah keterdesakan ekonomi yang dialami para petani. Kondisi ini memotivasi munculnya pemikiran petani mengalihfungsikan lahan pertanian ke sektor non-pertanan, atau menjual lahan tersebut kepada pengembang/developer. Hal ini sejalan dengan pendapat yang disampaikan oleh Fadholi (1991: 59) bahwa petani mengalami kesulitan dan permasalahan yang akan menyebabkan semakin tingginya alih fungsi lahan pertanian.

Kondisi ini belum dimediasi oleh pemerintah sebagai pihak pengambil keputusan. Sampai saat ini, belum ada wujud subsidi dan insentif pengurangan pajak yang diberikan kepada petani untuk mempertahankan lahan pertaniannya. Pemerintah juga belum secara intensif memotivasi para petani untuk mengakomodasi kemajuan ilmu pengetahuan dan teknologi dalam kegiatan pertanian. Proses bimbingan dan penyuluhan yang tersedia bagi petani juga masih terbatas adanya. Proteksi terhadap sektor pertanian beserta produk yang dihasilkan juga belum diusahakan secara optimal. Seperti biasa, harga hasil pertanian akan turun ketika musim panen tiba. Ini tentunya tidak kondusif terhadap konsistensi ketersediaan sumberdaya finansial yang dimiliki petani. Kondisi tersebut terkadang diperparah dengan absennya sumber-sumber subsidi yang tersedia bagi petani ketika terjadi gagal panen. Satu hal yang juga perlu disadari disini bahwa para petani di Bali pada umumnya mengkultivasi lahan yang relatif tidak luas. Sehingga mereka tidak memperoleh kontribusi finansial yang tinggi, kecuali jika petani memiliki kesempatan untuk menjadi penyakap lahan pertanian yang dimiliki orang lain.

\section{c. Aspek Lingkungan}

Aspek lingkungan yang mempengaruhi alih fungsi lahan pertanian di Kawasan Perkotaan Mangupura Kabupaten Badung, merupakan kumpulan faktor-faktor yang ditinjau dari karakteristik lingkungan dan posisi geografis lahan yang dialihfungsikan, yang meliputi:

\section{Faktor Kondisi Lahan Pertanian}

Semakin berkurangnya lahan pertanian di Kawasan Perkotaan Mangupura salah satunya disebabkan oleh adanya pembangunan ruang-ruang yang ada di sekitarnya. Pembangunan ini telah mengakibatkan terputusnya aliran irigasi dan memicu terjadinya pencemaran lingkungan, berupa pembuangan sampah maupun limbah cair ke lahan pertanian produktif. Kondisi ini menurunkan kualitas serta tingkat kesuburan lahan. Banyak lahan pertanian yang menjadi tandus dan tidak produktif untuk dikultivasi lagi. Kondisi ini sudah digarisbawahi oleh Sargent, 1976 dalam (Yunus, 2012: 86-87) dengan mengemukakan bahwa polusi air 
dan tanah, dan adanya gangguan terhadap saluran irigasi telah mengganggu aktivitas pertanian di kawasan perkotaan.

Selain itu, secara fisik lahan pertanian yang ada di Kawasan Perkotaan Mangupura berada pada site dengan topografi yang relatif datar. Lahan semacam ini menjadi incaran para pengembang/developer untuk dijadikan kompleks permukiman dan pelayanan, jasa, dan komersial. Menurut Colby, 1933 dalam (Yunus, 2012: 177-178) kawasan yang seperti ini akan memiliki kekuatan sentripetal (site forces). Kemudian kawasan dengan tofografi yang datar ini akan memberi kemudahan dalam pengelolaan fisik lahan, khususnya dalam pembangunan sarana dan prasarana pendukung, baik yang dibutuhkan untuk permukiman, fungsi perdagangan, jasa serta industri. Kondisi ini juga telah menjadi kekuatan yang mendorong semakin pesatnya alih fungsi lahan pertanian di Kawasan Perkotaan Mangupura.

\section{Faktor Lokasi}

Kawasan Perkotaan Mangupura yang berpusat di Kelurahan Sempidi, saat ini didesain sebagai kawasan pusat kota atau Central Business District (CBD). Pembangunan fasilitas umum dan sosial, seperti Kantor Pusat Pemerintahan Mangupraja Mandala, yang menjadi pusat dari kegiatan pelayanan masyarakat di Kabupaten Badung beserta infrastruktur pendukung lainnya, menunjukan keseriusan pemerintah untuk mencapai tujuan tersebut. Untuk mendukung aktivitas kehidupan masyarakat, pemerintah daerah telah secara bertahap melakukan berbagai usaha untuk mendorong terjadi pemanfaatan lahan. Ini termasuk pembangunan keruangan untuk kawasan pertokoan, perkantoran, gudang, industri dan perumahan.

Sebagai akibatnya, telah terjadi pemanfaatan lahan yang semakin padat, yang membawa dampak pada alih fungsi lahan pertanian menjadi kawasan terbangun. Berdasarkan hasil wawancara yang dilaksanakan sebagai bagian proses studi diperoleh data, bahwa harga lahan yang terletak di Kelurahan Sempidi, adalah lebih tinggi jika dibandingkan dengan lahan yang terletak lebih jauh dari pusat kota, seperti di Desa Kekeran dan Desa Mengwitani. Hal ini sesuai dengan teori lokasi yang dicetuskan oleh Von Thunen, dimana harga ekonomis lahan yang berada di dekat pusat kota Central Business District (CBD) lebih tinggi jika dibandingkan dengan lahan yang berlokasi di pinggiran kota.

\section{d. Aspek Regulasi}

Aspek regulasi yang dimaksud disini adalah kumpulan faktor-faktor yang berkaitan dengan peraturan penataan ruang baik yang melingkupi tatanan regulasi terkait perencanaan, pelaksanaan maupun pengendalian pemanfaatan ruang yang mempengaruhi alih fungsi lahan pertanian di Kawasan Perkotaan Mangupura Kabupaten Badung, merupakan. Aspek ini meliputi:

\section{Penegakan Hukum}

Permasalahan pelanggaran pemanfaatan ruang dan alih fungsi lahan pertanian yang terjadi di Kawasan Perkotaan Mangupura, mencerminkan masih lemah dan tidak berjalannya proses penegakan hukum terkait peraturan tata ruang. Penegakan hukum sesungguhnya merupakan tugas dan tanggung jawab dari Pemerintah Daerah Kabupaten Badung, tetapi kesuksesannya 
tidak terlepas dari peranserta dan partisipasi masyarakat. Kondisi terakhir ini dibutuhkan untuk memastikan bahwa aktivitas penataan ruang yang telah direncanakan bersifat aplikabel, dan tujuan pembangunan spasial di daerah tercapai. Dengan mengacu pada konsepsi yang ditawarkan oleh Soekanto, 1979 dalam (Mandey 2015: 79-82), berikut adalah faktor-faktor yang menyebabkan rendahnya penegakan hukum tata ruang di Kawasan Perkotaan Mangupura Kabupaten Badung antara lain:

(1) Faktor produk hukum, dimana peraturan tata ruang yang berlaku dan digunakan di Kabupaten Badung sampai saat ini, Rencana Tata Ruang Wilayah (RTRW) Kabupaten Badung, yang secara dasar hukumnya masih merupakan arahan dari kebijakan tata ruang, dan secara teknis tidak dapat digunakan sebagai dasar pemberian izin dan pengendalian pemanfaatan ruang.

(2) Faktor penegakan hukum, yang dimaksudkan disini adalah instansi atau Satuan Kerja Perangkat Daerah (SKPD) di Pemerintah Daerah Kabupaten Badung yang terkait dengan penataan ruang. SKPD yang memiliki tugas pokok dan fungsi (tupoksi) dalam penegakan hukum peraturan tata ruang adalah Satuan Polisi Pamong Praja (Satpol PP). Tetapi dalam melaksanakan tupoksinya, Satpol PP membutuhkan data dan informasi dari SKPD yang terlibat dalam kegiatan pemanfaatan ruang, yang tergabung dalam Badan Koordinasi Penataan Ruang Daerah (BKPRD) Kabupaten Badung. Namun dengan semakin tingginya pelanggaran dalam pemanfaatan ruang, kondisi ini mencerminkan kurangnya koordinasi oleh tim BKPRD Kabupaten Badung. Kondisi inilah yang telah memberi celah bagi masyarakat dan pihak pengembang, yang berujung pada peningkatan jumlah pelanggaran pemanfaatan ruang, termasuk salah satunya alih fungsi lahan pertanian di Kawasan Perkotaan Mangupura.

(3) Faktor sarana atau fasilitas, yang dimaksudkan adalah kurangnya sarana yang didedikasikan untuk mendukung operasional penertiban bangunan yang terbukti melakukan pelanggaran pemanfaatan ruang maupun kegiatan alih fungsi lahan pertanian. Pemerintah Daerah Kabupaten Badung belum mengalokasikan dana untuk pengadaan alat-alat berat yang dapat digunakan untuk mengatasi terjadinya pelanggaran pemanfaatan ruang. Tindakan penegakan hukum tata ruang dan penertiban pelanggaran pemanfaatan ruang akan sulit untuk dilakukan tanpa adanya dukungan anggaran.

(4) Faktor masyarakat dan lingkungan dimana hukum diterapkan. Berdasarkan hasil wawancara, sebagian besar masyarakat di Kawasan Perkotaan Mangupura masih belum paham dan mengetahui mengenai peraturan tata ruang. Sebagian besar masyarakat menganggap peraturan tata ruang itu tidak ada, dan tidak penting untuk dilakukan. Disinilah perlu dilakukan pendekatan dan sosialisasi oleh pemerintah untuk meminimalisir dan mengatasi semakin banyak terjadinya pelanggaran pemanfaatan ruang dan alih fungsi lahan pertanian.

\section{Sosialisasi Peraturan Tata Ruang.}

Sosialisasi peraturan sangat penting untuk dilakukan agar masyarakat memiliki pengetahuan terkait peraturan tata ruang. Sosialisasi berfungsi sebagai sarana untuk memberikan arahan dan pengertian kepada masyarakat, sehingga maksud dan tujuan dari peraturan penataan ruang bisa tercapai. Berdasarkan hasil wawancara dan observasi lapangan, hampir keseluruhan narasumber terutama masyarakat, mengakui tidak mengetahui dan kurang 
paham terhadap peraturan tata ruang yang berlaku. Salah satu akibat dari kurangnya pemahaman masyarakat terhadap peraturan tata ruang, adalah terjadinya pemanfaatan ruang yang tidak sesuai, salah satunya alih fungsi lahan pertanian.

\section{Strategi Pengendalian Alih Fungsi Lahan Pertanian di Kawasan Perkotaan Mangupura}

Menurut Undang-Undang Nomor 26 Tahun 2007 tentang Penataan Ruang, menjelaskan bahwa pengendalian pemanfaatan ruang merupakan suatu upaya untuk mewujudkan tertib tata ruang, yang dilakukan melalui penetapan peraturan zonasi, perizinan, pemberian insentif dan disinsentif serta pengenaan sanksi. Dengan adanya kegiatan pengendalian pemanfaatan ruang, maka akan dapat menghindari kemungkinan terjadinya penyimpangan pemanfaatan ruang yang tidak terkendali, dan tidak sesuai dengan rencana pemanfaatan ruang (Ibrahim, 1998: 32). Secara umum proses pengendalian pemanfaatan ruang dapat dilihat pada Gambar 5.

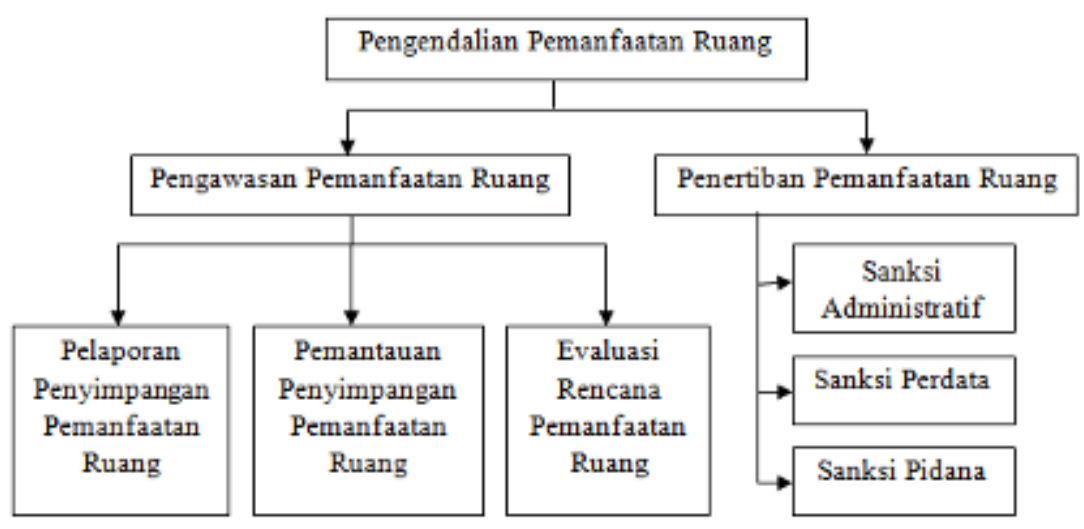

Gambar 5. Lingkup Kegiatan Pengendalian Pemanfaatan Ruang Sumber: Undang-Undang No. 26 Tahun 2007 tentang Penataan Ruang

Tabel 7. berikut menampilkan hasil wawancara terkait strategi pengendalian alih fungsi lahan pertanian di Kawasan Perkotaan Mangupura.

Tabel 7. Hasil Wawancara Mengenai Strategi Pengandalian Alih Fungsi Lahan Pertanian

\begin{tabular}{|c|c|c|c|c|c|c|c|c|c|}
\hline \multirow[t]{2}{*}{ Narasumber } & \multicolumn{6}{|c|}{ Instrumen Pengendalian Pemanfaatan Ruang } & \multicolumn{3}{|c|}{$\begin{array}{c}\text { Instansi Pelaksana } \\
\text { Pemanfaatan Ruang }\end{array}$} \\
\hline & $\begin{array}{l}\text { Penetapan } \\
\text { Peraturan }\end{array}$ & $\begin{array}{l}\text { Insentit } \& \\
\text { Disintensif }\end{array}$ & $\begin{array}{c}\text { Perizinan } \\
\text { Lokasi }\end{array}$ & $\begin{array}{c}\text { Pemberian } \\
\text { Sanksi }\end{array}$ & $\begin{array}{c}\text { Kajian } \\
\text { Kebjiakan }\end{array}$ & Sosialisasai & $\begin{aligned} \text { Ketegasan } \\
\text { Aparat }\end{aligned}$ & $\begin{array}{l}\text { Koordinasi } \\
\text { SKPD }\end{array}$ & $\begin{array}{l}\text { Kerasama } \\
\text { Penerinat } \\
\text { Masyaratat }\end{array}$ \\
\hline $\begin{array}{l}\text { Penduduk } \\
\text { Pendatang }\end{array}$ & 1 & 3 & 0 & 2 & 0 & 2 & 4 & 1 & 2 \\
\hline $\begin{array}{l}\text { Penduduk Asli / } \\
\text { Pemilik Lahan }\end{array}$ & 0 & 4 & 0 & 0 & 0 & 3 & 6 & 0 & 2 \\
\hline $\begin{array}{c}\text { Tokoh } \\
\text { Masyarakat }\end{array}$ & 1 & 3 & 1 & 0 & 1 & 1 & 5 & 0 & 1 \\
\hline $\begin{array}{c}\text { Instansi } \\
\text { Pemerintah }\end{array}$ & 9 & 6 & 1 & 2 & 1 & 5 & 4 & 4 & 3 \\
\hline $\begin{array}{l}\text { Developer / } \\
\text { Pengembang }\end{array}$ & 1 & 1 & 0 & 0 & 0 & 0 & 2 & 1 & 0 \\
\hline $\begin{array}{l}\text { Pengamat } \\
\text { Tata Ruang }\end{array}$ & 1 & 1 & 0 & 0 & 0 & 1 & 0 & 0 & 1 \\
\hline Jumlah & 13 & 18 & 2 & 4 & 2 & 12 & 21 & 6 & 9 \\
\hline
\end{tabular}

Sumber: Penulis, 2017 
Berdasarkan hasil wawancara dan analisa, terdapat beberapa strategi pengendalian alih fungsi lahan pertanian di Kawasan Perkotaan Mangupura yang secara umum bisa diklasifikasikan menjadi dua aspek, yaitu aspek instrumen pengendalian pemanfaatan ruang, dan aspek instansi pelaksana pengendalian pemanfaatan ruang.

\section{a. Instrumen Pengendalian Pemanfaatan Ruang.}

Instrumen pengendalian pemanfaatan ruang memberi penekanan pada strategi pengendalian yang harus dilakukan oleh Pemerintah Daerah Kabupaten Badung, berdasarkan pada produk hukum, kebijakan dan peraturan tata ruang. Beberapa strategi yang memiliki peluang untuk dilakukan oleh Pemerintah Daerah Kabupaten Badung, terkait dengan instrumen pengendalian pemanfaatan ruang untuk meminimalisir terjadinya alih fungsi lahan pertanian adalah:

\section{Penetapan Peraturan Tata Ruang}

Salah satu peraturan yang dijadikan landasan dalam pembangunan adalah peraturan tata ruang, yang bertujuan untuk menciptakan tata ruang yang aman, nyaman, produktif dan berkelanjutan. Peraturan tata ruang yang ditetapkan dan dijadikan pedoman dalam pemanfaatan ruang di Kabupaten Badung saat ini adalah Rencana Tata Ruang Wilayah (RTRW). Tetapi secara teknis, RTRW merupakan arahan peraturan zonasi, masih bersifat makro, dan ruang lingkup wilayah perencanaan masih luas, serta hanya dapat dijadikan sebagai acuan dalam menerbitkan izin lokasi dengan skala wilayah yang luas, sehingga tidak tepat dijadikan acuan dalam penerbitan Izin Mendirikan Bangunan (IMB) untuk pemanfaatan ruang yang lebih kecil dan spesifik. Menurut Peraturan Menteri Pekerjaan Umum Nomor 20 Tahun 2011 tentang Rencana Detail Tata Ruang (RDTR) dan Peraturan Zonasi (PZ), mejabarkan dokumen RDTR dan PZ yang dapat menjadi rujukan, dan landasan hukum yang kuat untuk menerbitkan izin pemanfaatan ruang dan IMB. Selain itu, di dalam RDTR dan PZ sudah tercantum secara lebih mendetail mengenai jenis fungsi dan peruntukkan bangunan yang diperbolehkan/tidak untuk dibangun pada suatu kawasan tertentu. Ini akan memudahkan pengendalian, lebih spesifik dan mudah dalam pengimplementasiannya di lapangan. Dengan demikian Pemerintah Kabupaten Badung harus segera menetapkan RDTR dan PZ, untuk dijadikan acuan penerbitan IMB.

\section{Pemberian Insentif dan Disinsentif}

Pemberian insentif dan disinsentif dilakukan untuk meningkatkan upaya pengendalian pemanfaatan ruang, dalam rangka mewujudkan pemanfaatan ruang yang sesuai dengan rencana tata ruang. Pemberian insentif merupakan suatu upaya untuk memberikan imbalan atau penghargaan, terhadap pelaksanaan kegiatan pemanfaatan ruang yang sejalan dengan rencana tata ruang. Berdasarkan hasil wawancara, mengenai bentuk pemberian insentif yang dilakukan oleh Pemerintah Daerah Kabupaten Badung, terutama pada petani atau pemilik lahan pertanian yang masih mempertahankan eksistensi lahan pertanian produktifnya antara lain:

(1) Pemerintah Kabupaten Badung telah memberikan insentif berupa pengurangan pajak terhadap lahan pertanian produktif, dengan mengacu pada Peraturan Bupati Nomor 89 Tahun 2012 tentang Pengurangan Pajak Bumi dan Bangunan Pedesaan dan Perkotaan 
Untuk Kondisi Tertentu Objek Pajak Pada Jalur Hijau dan Kawasan Limitasi. Rincian pengurangan pajak terhadap lahan pertanian produktif sebesar $20 \%$ sampai dengan $80 \%$ dari NJOP lahan, dan pembebasan pajak $100 \%$ terhadap lahan pertanian produktif yang ditetapkan sebagai Kawasan Jalur Hijau (KJH).

(2) Pembangunan sarana prasarana dan infrastruktur berupa pembangunan balai dan pura subak, balai timbang, koperasi pertanian, perbaikan saluran dan bendungan irigasi, dan perbaikan jalan subak untuk mempermudah kerja petani dalam mengolah lahan pertanian.

(3) Pemberian subsidi kepada petani berupa bantuan pupuk baik organik maupun anorganik, pemberian bibit dan alat-alat pertanian, bantuan dana abadi sebesar Rp 50.000.000,00 kepada setiap subak yang ada di Kabupaten Badung yang dapat digunakan secara swakelola untuk menata dan memperbaiki saluran irigasi dan pematang sawah yang jebol maupun rusak.

(4) Memberikan penyuluhan, sosialisasi dan bimbingan teknis mengenai kegiatan pertanian, mengadakan program Asuransi Usaha Tani Padi (AUTP) berupa pemberian subsidi dalam pengajuan premi asuransi, dan mensinergikan kegiatan pertanian dengan pariwisata, dimana hasil pertanian lokal dijadikan sebagai komuditi untuk mendukung kebutuhan pangan pariwisata, dan mengadakan lomba subak serta pemberian penghargaan kepada subak yang dapat mempertahankan eksistensi lahan pertaniannya.

Sedangkan disinsentif sebagai perangkat untuk mencegah, membatasi pertumbuhan dan mengurangi kegiatan yang tidak sejalan dengan rencana tata ruang. Bentuk pengenaan disinsentif yang dilakukan terutama pada pemanfaatan ruang yang melanggar peraturan penataan ruang antara lain dengan tidak memberikan IMB kepada bangunan yang berdiri diatas lahan pertanian, dan pencabutan pengurangan subsidi pajak bagi lahan pertanian yang mengalami alih fungsi menjadi bangunan.

\section{Perizinan Lokasi.}

Perizinan merupakan langkah awal sebagai dasar dalam kegiatan pengawasan dan penertiban pemanfaatan tata ruang. Strategi pengendalian pemanfaatan ruang melalui penerbitan perizinan yang dapat dilakukan oleh Pemerintah Kabupaten Badung, antara lain:

(1) Tidak memberikan IMB pada kegiatan yang dilaksanakan pada kawasan limitasi/lindung seperti kawasan hutan lindung dan taman hutan raya, kawasan resapan air, kawasan suci, kawasan sempadan pantai, sungai dan jurang, kawasan cagar budaya, kawasan rawan bencana, kawasan pertanian, dan kawasan jalur hijau, kecuali kegiatan tersebut dapat mendukung dan tidak merusak fungsi ruang.

(2) Apabila terjadi penggusuran, pembongkaran, akibat dari perencanaan dan pembangunan sarana prasarana, seperti jalan raya dan fasilitas umum lainnya, kerusakan akibat bencana alam seperti banjir, tanah longsor, atau kebakaran, ganti rugi dan kompensasi terhadap lahan tidak akan diberikan bagi bangunan yang tidak memiliki IMB.

(3) Bekerja sama dengan pihak Perusahaan Listrik Negara (PLN) dan Perusahaan Daerah Air Minum (PDAM) untuk tidak memberikan pelayanan listrik, dan air bersih kepada bangunan yang tidak memiliki IMB, dan menutup akses jaringan pelayanan bagi bangunan yang tidak sesuai dengan peraturan yang berlaku. 
(4) Selain penerbitan izin, Pemerintah Daerah Kabupaten Badung berkewajiban melakukan tindakan pengawasan terhadap kegiatan pemanfaatan ruang. Tindakan pengawasan dilakukan sebelum maupun sesudah IMB diberikan. Pengawasan yang dilakukan sebelum izin diberikan, dilakukan dengan mewajibkan pemohon untuk melengkapi berbagai persyaratan yang dibutuhkan untuk memperoleh izin. Sedangkan pengawasan yang dilakukan sesudah izin diberikan, bertujuan untuk melihat kesesuaian kegiatan tersebut dengan ketentuan yang tercantum dalam izin yang telah diberikan.

4. Pemberian Sanksi terhadap Pelanggaran Pemanfaatan Ruang.

Proses pemberian sanksi merupakan salah satu pengendalian pemanfaatan ruang, yang berkaitan dengan tindakan penertiban pada kegiatan pemanfaatan ruang yang tidak sesuai dengan peruntukkan kawasannya. Penertiban terhadap pemanfaatan ruang yang tidak sesuai dengan rencana tata ruang, diselenggarakan dalam bentuk pengenaan sanksi sesuai dengan peraturan perundang-undangan yang berlaku. Strategi pengendalian pemanfaatan ruang sesuai dengan RTRW, melalui pemberian sanksi berupa: 1) Sanksi adminsitratif, merupakan sanksi yang dikenakan terhadap pelanggaran pemanfaatan ruang yang berakibat pada terhambatnya program pemanfaatan ruang. Sanksi tersebut dapat berupa peringatan tertulis, penghentian sementara kegiatan, penutupan lokasi, pencabutan izin, pembatalan izin, pembongkaran bangunan, denda administratif, dan pemulihan fungsi ruang. 2) Sanksi pidana, pelanggaran terhadap ketentuan yang telah ditetapkan dalam RTRW dapat dikenai sanksi pidana. Besarnya sanksi pidana yang dapat dikenakan berupa pidana kurungan paling lama enam bulan, atau pidana denda paling banyak Rp 50.000.000,00 (lima puluh juta rupiah). Pengenaan sanksi tidak hanya diberikan kepada pemanfaat ruang yang melakukan pelanggaran pemanfaatan ruang saja, tetapi dikenakan kepada pejabat pemerintah yang menerbitkan izin yang tidak sesuai dengan rencana tata ruang.

\section{Kajian Terhadap Program Pembangunan dan Peraturan Tata Ruang.}

Pemerintah Daerah Kabupaten Badung diharapkan mengkaji kembali beberapa program pembangunan, dan penataan ruang yang telah ditetapkan sebelumnya. Melalui kajian ini diharapkan agar kegiatan pembangunan bisa berjalan, dan alih fungsi lahan pertanian dapat diminimalisir dan diantisipasi sebelumnya. Beberapa strategi dan langkah yang dapat dilakukan oleh Pemerintah Daerah Kabupaten Badung antara lain: 1) mengkaji kembali pembangunan sarana dan prasarana seperti pembangunan akses jalan yang melintasi kawasan pertanian produktif; 2) melakukan kajian secara intensif apabila dalam kebijakan dan peraturan daerah akan membuka lahan sebagai kawasan terbangun, terutama pada kawasan pertanian yang produktif; 3) membuka kawasan pertanian baru terutama sawah pada daerah yang mendukung aktivitas pertanian; dan 4) menyesuaikan dan mengkaji ulang nomenklatur dalam peraturan daerah mengenai penataan ruang yang sudah lama dan tidak dapat diaplikasikan lagi.

\section{b. Instansi Pelaksana Pengendalian Pemanfaatan Ruang}

Instansi pelaksana pengendalian pemanfaatan ruang lebih menekankan pada strategi pengendalian yang harus dilakukan oleh Pemerintah Daerah Kabupaten Badung, yang melibatkan pejabat dan instansi berwewenang melakukan pengendalian pemanfaatan ruang. 
Beberapa strategi yang berpotensi untuk dilakukan terkait instansi pengendali alih fungsi lahan pertanian adalah:

\section{Ketegasan Aparat Penegak Hukum.}

Satpol PP wajib melakukan koordinasi dengan tim BKPRD berdasarkan acuan dan pedoman yang jelas. Untuk ini Pemerintah Daerah Kabupaten Badung harus membuat dan menetapkan petunjuk teknis yang berdasarkan Standart Operating Procedure (SOP) yang dapat dijadikan acuan dalam pelaksanaan koordinasi ini. Tindakan ini akan mencegah terjadinya pertentangan dengan peraturan dan perundang-undangan lainnya yang berlaku pada saat yang sama.

\section{Koordinasi antar SKPD.}

Dalam rangka mengkoordinasikan penyelenggaraan penataan ruang, dan kerjasama antar sektor di bidang penataan ruang dibentuk BKPRD Kabupaten. Susunan organisasi, tata kerja, dan tugas BKPRD Kabupaten ditetapkan dengan Keputusan Bupati. Penetapan ini bertujuan agar kegiatan penataan ruang terkoordinasi dan tidak berjalan sendiri-sendiri. Koordinasi antar SKPD ini juga bertujuan agar proses penataan ruang di Kabupaten Badung bisa berjalan dengan efektif.

\section{Kerjasama Pemerintah Daerah dengan Masyarakat.}

Pengendalian pemanfaatan ruang, merupakan suatu kebutuhan untuk mengefektifkan pencapaian tujuan penataan ruang. Proses pengendalian alih fungsi lahan pertanian, tidak akan berhasil, tanpa didukung oleh partisipasi masyarakat. Peran serta masyarakat dalam pengendalian pemanfaatan ruang bisa dilakukan dalam beberapa cara, termasuk: 1) memberikan masukan terkait arahan dan/atau Peraturan Zonasi, perizinan, pemberian insentif dan disinsentif serta pengenaan sanksi; 2) keikutsertaan masyarakat dalam memantau dan mengawasi pelaksanaan rencana tata ruang yang telah ditetapkan; 3) pelaporan kepada instansi yang berwenang dalam jika ditemukan pelanggaran pemanfaatan ruang; serta 4) pengajuan keberatan terhadap keputusan pejabat yang berwenang terhadap pembangunan yang dianggap tidak sesuai dengan rencana tata ruang.

\section{Kesimpulan}

Alih fungsi lahan pertanian menjadi kawasan terbangun di Kawasan Perkotaan Mangupura, Kabupaten Badung mengindikasikan bahwa peraturan daerah terkait peraturan tata ruang yang melindungi eksistensi lahan pertanian tidak berjalan sebagaimana mestinya. Studi ini menemukan bahwa faktor-faktor penyebab terjadinya alih fungsi lahan pertanian ini meliputi: 1) aspek sosial, termasuk tingginya pertumbuhan penduduk, sistem waris, dan semakin kecilnya minat generasi muda untuk bertani; 2) aspek ekonomi yang mencakup faktor tingginya nilai investasi lahan dan faktor keterdesakan ekonomi petani; 3) aspek lingkungan yang meliputi kondisi dan lokasi lahan pertanian serta ketersediaan sarana prasarana; 4) aspek regulasi yang merangkul faktor rendahnya penegakan hukum dan kurangnya sosialisasi peraturan tata ruang kepada masyarakat.

Sementara itu, studi ini juga mencoba merumuskan strategi bagaimana alih fungsi lahan pertanian yang semakin meningkat dari tahun ke tahun ini bisa dikendalikan. Hasil studi 
menunjukan bahwa strategi ini dapat mempertimbangkan dua aspek dasar yaitu:1) aspek ketersediaan instrumen pengendalian pemanfaatan ruang yang meliputi perlunya penetapan peraturan tata ruang yang lebih detail, sebagai alat ukur sebelum izin pemanfaatan ruang bisa dikeluarkan, pemberian insentif dan disinsentif, pemberian perizinan lokasi, pemberian sanksi terhadap pelanggaran pemanfaatan ruang, dan melakukan kajian kembali terhadap program-program pembangunan; 2) aspek instansi pelaksana pengendalian pemanfaatan ruang, yang antara lain merumuskan perlunya ketegasan dari aparat penegak hukum, ditingkatkannya koordinasi antar instansi pemerintah daerah, dan melakukan kerjasama dengan masyarakat dalam pengendalian pemanfaatan ruang. Sinergi antara kedua aspek pengendalian tersebut di atas beserta pemahaman akan faktor-faktor pemicu terjadinya alih fungsi lahan pertanian di Kawasan Perkotaan Mangupura, Kabupaten Badung diharapkan akan mampu mengendalikan dan mengatasi alih fungsi lahan pertanian ke depannya.

\section{Daftar Pustaka}

Catur, T. B. (2010). Dampak Alih Fungsi Lahan Pertanian Ke Sektor Non Pertanian Terhadap Ketersediaan Beras di Kabupaten Klaten Provinsi Jawa Tengah. Jurnal Caraka Tani XXV, 1(1), 38-42.

Daldjoeni, N. (1992). Geografi Baru Organisasi Keruangan Dalam Teori dan Praktek. Bandung: Alumni.

Dinas Cipta Karya Kabupaten Badung. (2015). Laporan Akhir Pemetaan Pola Penggunaan Lahan Kota Mangupura. Denpasar: Ganesha.

Fadholi, H. (1991). Ilmu Usaha Tani. Jakarta: Penebar Swadaya.

Harsono, B. (2008). Hukum Agraria Indonesia Sejarah Pembentukan Undang Undang Pokok Agraria Isi Dan Pelaksanaannya. Jakarta: Djambatan.

Herlina. (2002). Orientasi Nilai Kerja Pemuda Pada Keluarga Petani Perkebunan, Studi Kasus: Desa Sukajembar, Kecamatan Sukanagara, Kabupaten Cianjur, Jawa Barat. (tesis), Institut Pertanian Bogor, Bogor.

Hermit, H. (2009). Teknik Penaksiran Harga Tanah Perkotaan Teori dan Penilaian Tanah. Bandung: CV. Mandar Maju.

Ibrahim, S. (1998). Pengendalian Pemanfaatan Ruang di Wilayah Kabupaten Dati II. Jurnal $P W K, 9(2), 26-38$.

Kementerian Pekerjaan Umum. (2011). Peraturan Menteri Pekerjaan Umum Republik Indonesia Nomor 20 Tahun 2011 tentang Rencana Detail Tata Ruang dan Peraturan Zonasi Kabupaten/Kota.

Kustiawan, I. (1997). Permasalahan Konversi Lahan Pertanian dan Implikasinya Terhadap Penataan Ruang Wilayah Studi Kasus: Wilayah Pantura Jawa Barat. Jurnal PWK, $8(1)$.

Lestari, T. (2010). Konversi Lahan Pertanian Dan Perubahan Taraf Hidup Rumahtangga Petani (Kasus pembangunan X di Kampung Cibeurem Sunting dan Kampung Pabuaran, Kelurahan Mulyaharja, Kecamatan Bogor Selatan, Kota Bogor, Provinsi Jawa Barat). (skripsi), Institut Pertanian Bogor, Bogor.

Maleong, R. J. (2007). Metodologi Penelitian Kualitatif. Bandung: Remaja Rosdakarya Offset.

Pambudi, A. (2008). Analisis Nilai Ekonomi Lahan (Land Rent) Pada Lahan Pertanian dan Permukiman di Kecamatan Ciampea, Kabupaten Bogor. (skripsi), Institut Pertanian Bogor, Bogor.

Pemerintah Republik Indonesia. (2007). Undang Undang Republik Indonesia Nomor 26 Tahun 2007 tentang Penataan Ruang. 
Pemerintah Republik Indonesia. (2009). Peraturan Pemerintah Nomor 67 Tahun 2009 tentang Pemindahan Ibukota Kabupaten Badung dari Wilayah Kota Denpasar ke Wilayah Kecamatan Mengwi, Kabupaten Badung, Provinsi Bali.

Pemerintah Daerah Kabupaten Badung. (2013). Peraturan Daerah Nomor 26 Tahun 2013 tentang Rencana Tata Ruang Wilayah Kabupaten Badung 2013-2033.

Puspasari, A. (2012). Faktor-Faktor yang Mempengaruhi Alih Fungsi Lahan Pertanian dan Dampaknya Terhadap Pendapatan Petani Studi kasus: Desa Kondangjaya, Kecamatan Karawang Timur, Kabupaten Karawan. (tesis), Institut Pertanian Bogor, Bogor.

Saroso, W. (2002). A Framework for The Analysis of Urban Sustainability Linking Theory and Practice. Urban Regional Development Series, 2, 5-21.

Sudarmaji. (2008). Pembangunan Berkelanjutan, Lingkungan Hidup dan Otonomi Daerah.Yogyakarta: Universitas Gajah Mada.

Sugiyono. (2014). Metode Penelitian Pendidikan: Pendekatan Kuantitatif, Kualitatif, dan $R \& D$. Bandung: Alfabeta.

Widoatmodjo, S (2007) Cara Cepat Memulai Investasi Saham. Jakarta: PT Elex Media Komputindo.

Winoto, J. (2005). Kebijakan Pengendalian Alih Fungsi Tanah Pertanian dan Implementasinya. Jakarta: Kementerian Koordinator Bidang Perekonomian.

Yunus, H. S. (2012). Struktur Tata Ruang Kota. Yogyakarta: Pustaka Pelajar. 